\title{
A better understanding of the ecological conditions for Leontopodium alpinum Cassini in the Swiss Alps
}

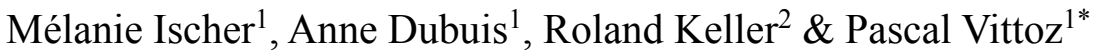 \\ ${ }^{1}$ Department of Ecology and Evolution, University of Lausanne, CH-1015 Lausanne, \\ Switzerland. \\ ${ }^{2}$ Primerose 6, CH-1007 Lausanne, Switzerland.
}

\author{
* Corresponding author: \\ Pascal Vittoz, Department of Ecology and Evolution, University of Lausanne, Biophore \\ Building, CH-1015 Lausanne, Switzerland; phone: ++41 21692 4270; fax: ++41 21692 \\ 4165; e-mail: pascal.vittoz@unil.ch
}

\begin{abstract}
Although Leontopodium alpinum is considered to be threatened in many countries, only limited scientific information about its autecology is available. In this study, we aim to define the most important ecological factors which influence the distribution of $L$. alpinum in the Swiss Alps. These were assessed at the national scale using species distribution models based on topoclimatic predictors and at the community scale using exhaustive plant inventories. The latter were analysed using hierarchical clustering and principal component analysis, and the results were interpreted using ecological indicator values.

L. alpinum was found almost exclusively on base-rich bedrocks (limestone and ultramaphic rocks). The species distribution models showed that the available moisture (dry regions, mostly in the Inner Alps), elevation (mostly above 2000 m.a.s.1.) and slope (mostly $>30^{\circ}$ ) were the most important predictors. The relevés showed that L. alpinum is present in a wide range of plant communities, all subalpine-alpine open grasslands, with a low grass cover. As a light-demanding and short species, L. alpinum requires light at ground level; hence, it can only grow in open, nutrient-poor grasslands. These conditions are met in dry conditions (dry, summer-warm climate, rocky and draining soil, south-facing aspect and/or steep slope), at high elevations, on oligotrophic soils and/or on windy ridges. Base-rich soils appear to also be essential, although it is still unclear if this corresponds to physiological or ecological (lower competition) requirements.
\end{abstract}

Keywords alpine grasslands; autecology; phytosociology; species distribution models; Switzerland 


\section{Introduction}

Leontopodium alpinum is a perennial herbaceous hemicryptophyte that grows $8-20 \mathrm{~cm}$ high (Aeschimann et al. 2004) and is characterised by 2-10 small yellow capitula surrounded by white and woolly bracts visited by a wide range of insects (Erhardt 1993). Its colour, shape, rarity, and legendary inaccessibility have conferred upon it a high symbolic value in alpine regions. Indeed, this species is prized by tourists and botanists (Erhardt 1993); its common name, edelweiss, comes from German and means noble (edel) and white (weiss; Dweck 2004).

L. alpinum is mostly found in alpine areas, ranging from the Pyrenees to the Central Balkans in Bulgaria (Wagenitz 1979). The genus is native to the Tibetan Plateau and might have migrated during the Pleistocene, when a continual distribution between Asia and Europe was possible (Blöch et al. 2010). This species has been mostly studied with regard to its pharmaceutical properties (antibacterial, anti-inflammatory and analgesic properties; Dobner et al. 2003, 2004; Speroni et al. 2006). In Switzerland, L. alpinum has been domesticated (var. Helvetica) and is now cultivated to produce anti-aging creams, sunscreens, and liquor (Carron et al. 2007) or for ornamental purposes (Sigg 2008).

Despite the symbolic value of L. alpinum in the Alps, limited scientific information about its autecology is available, with the literature being mostly restricted to descriptive floras based on expert knowledge, and we could not find any descriptive study clearly based on detailed field data. Wagenitz (1979) and Oberdorfer and Müller (1990) indicate that this plant is a light-demanding species found on sunny, rocky grasslands or on cliffs (ledges or crevices) from $1600 \mathrm{~m}$ to $2350 \mathrm{~m}$ asl $(-3000 \mathrm{~m})$ in regions with warm summers, on base-rich, mostly calcareous, neutral and mainly humus-rich soils. According to Delarze and Gonseth (2008), this species is found in two distinct phytosociological alliances in Switzerland, Seslerion and Elynion, both of which are characterised by alkaline to neutral calcareous soils. Seslerion is distributed on sunny slopes between $1000 \mathrm{~m}$ and $2400 \mathrm{~m}$ asl, on dry and stony soils. Elynion is restricted to windy ridges between $2000 \mathrm{~m}$ and $3000 \mathrm{~m}$, which are only partly protected by snow in winter. Wagenitz (1979) and Oberdorfer and Müller (1990) add Potentillion caulescentis on limestone cliffs as a possible alliance. Rey et al. (2011) recently published a synthesis based on previous floras and the extensive experience of the main author, adding to the previous descriptions a preference for a subcontinental climate on slightly dry, oligotrophic soils, with a $\mathrm{pH}$ range of 5.5-8.

Although L. alpinum is considered as of "Least Concern" on the Swiss Red List (Moser et al. 2002), it is not a widespread species. Some populations include hundreds of plants; however, most of the populations are restricted to a few individuals, and the species is far from being present in all Seslerion or Elynion areas in the Alps. Unfortunately, no monitoring of its populations exists, though many botanists have an impression of decreasing populations. Indeed, this species is considered to be endangered and is protected in most countries or regions where it occurs (cf. review of its status in Rey et al. (2011) and for Switzerland at http://www.infoflora.ch/). Collection by tourists because of the beauty and symbolic value of this species is most likely responsible for the population decreases (Jean 1947; Wagenitz 1979; Rey et al. 2011).

In order to ensure optimal conservation of L. alpinum, it is important to identify dominant ecological factors in its distribution and therefore to back up the existing expert knowledge with field measurements (evidence-based conservation; e.g. Arlettaz et al. 2010). Distribution models are effective tools to obtain reliable information on the ecology of species (Guisan and Zimmermann 2000) because they allow detecting and ranking ecological factors affecting species fitness (Elith and Leathwick 2009), they produce faithful habitat suitability maps (Le Lay et al. 2010), and the use of such models is possible with rare or uncommon species 
(Engler et al. 2004). Exhaustive phytosociological relevés, which are numerous in Switzerland (Schaminée et al. 2009), offer a quick way to obtain data on many populations, with partner species giving indirect indications of ecological conditions (Deil 2005; Vittoz et al. 2006).

This study aimed to improve our knowledge regarding the necessary ecological conditions for L. alpinum in the Swiss Alps. In particular, we aimed to identify the most important ecological factors explaining the distribution of this species and to obtain a complete overview of the habitats in which the plant can grow. For this, (1) we modelled species distribution on the basis of 344 recorded occurrences, geology and five topoclimatic predictors to identify important ecological factors at the national scale and produce a map of potential habitats and (2) we performed clustering and multivariate analyses on 249 exhaustive plant inventories, interpreted with the help of ecological indicator values, to study the species ecological range at the community scale.

\section{Materials and methods}

\section{Study area}

The entire area of the Swiss Alps, representing $60 \%$ of Switzerland, was considered in this study. Due to their proximity to the Atlantic Ocean and the Mediterranean Sea, the Outer Alps are characterised by a wet, suboceanic climate. Conversely, some valleys in the Inner Alps are protected from rainfall by high mountains and experience a dry, subcontinental climate.

\section{Floristic data}

The existing data on L. alpinum were collected, either in the form of exhaustive species lists (phytosociological relevés) or from isolated observations. Relevés were collected from the literature (Braun-Blanquet 1969; Galland 1982; Reinalter 2004; Steiner 2002), from personal data obtained in previous projects (Randin et al. 2010) and from unpublished data (M. Ischer, J.-L. Richard, M. Schütz, R. Keller). All Swiss relevés were retained, without consideration of the size of the inventoried plot or the availability of exact coordinates. The vascular plant nomenclature is according to Aeschimann et al. (2004).

Isolated observations were mainly provided by Info Flora (Swiss Floristic Network; http://www.infoflora.ch/) and completed by occurrences in relevés. Only observations with a horizontal accuracy of 100 metres or less were retained for the models. 174 of the 344 available occurrences were from the relevés.

\section{Environmental data}

The species distribution in relation to geology was evaluated by counting the number of $L$. alpinum occurrences in each geological category. We used a geotechnical map at a 1:200,000 scale (Swiss Geotechnical Commission, http://www.sgtk.ch) in which the substrates are divided into 30 categories defined by bedrock type or granulometry for recent deposits. These categories were simplified into four categories: purely calcareous bedrocks, mixed bedrocks potentially with limestone (e.g., moraines, alluvial deposits, conglomerates), ultramaphic bedrocks and base-poor bedrocks (e.g., granite, quartzite).

In the species distribution models, we used three climatic and two topographic predictors, corresponding to the ecological factors susceptible to influence L. alpinum distribution on the basis of previous descriptions and generally considered as important and complementary ecological variables to explain species distribution in mountain environments (Körner 2003). The climatic predictors were calculated based on temperature and precipitation data recorded 
by MeteoSwiss (www.MeteoSwiss.ch) and interpolated with a 25-m resolution digital elevation model (see Zimmermann and Kienast 1999 for methodology). We used the mean temperature for the growing season (June to August, in ${ }^{\circ} \mathrm{C}$ ), the average moisture index over the growing season (average value of the balance between precipitation and potential evapotranspiration in $\mathrm{mm} \cdot \mathrm{day}^{-1}$ ) and the sum of solar radiation for the growing season (in $\mathrm{kJ} \cdot \mathrm{m}^{-2} \cdot \mathrm{yr}^{-1}$ ). The topographic predictors were derived from the digital elevation model. We used the slope (in degrees) and the topographic position (an integrated measure of topographic features; Zimmermann et al. 2007); positive values of topographic position indicate ridges, whereas negative values indicate valleys.

\section{Species distribution models}

To restrain the study area considered in the models to plausible areas for L. alpinum, a mask was created by removing the urbanised areas, glaciers and lakes. Moreover, only elevations higher than $1300 \mathrm{~m}$ asl were retained because no current occurrence is reported at lower elevations and the large majority of observations are above $1500 \mathrm{~m}$.

Out of the 344 available observations, we randomly selected occurrences separated by a minimum distance of 250 metres to avoid spatial autocorrelation. This selection was repeated 20 times, to test for potential differences in the models due to occurrence selection, retaining an average of 214 occurrences (see App. 1 in supplemental archives for distances between occurrences before and after disaggregation). Absences were not directly available because occurrences were mainly observations of presences only, without recorded absences. The use of other phytosociological relevés in the Swiss Alps could have provided real absences, but these data are not digitalized or they issued from regional research projects and absences would have been aggregated, bringing biases in models. For these reasons, we used pseudoabsences to calibrate the models (Engler et al. 2004). Using Hawth's Analysis Tools in ArcGIS (2004), we randomly generated $10^{\prime} 000$ pseudo-absences in the entire study area, as defined in the preceding paragraph. We used all the pseudo-absences during the model calibration but gave to each of them a weight equal to the number of occurrences divided by $10^{\prime} 000$, as recommended by Wisz and Guisan (2009) and Barbet-Massin et al. (2012).

The models were computed using the library BioMod (Thuiller et al. 2009) in R (v.2.14.1; R Development Team 2011). Four model types were computed to obtain a reliable probability regarding the presence of L. alpinum: generalised linear models (GLM; McCullagh and Nelder 1989) with a polynomial term and a stepwise procedure (computed with the Akaike information criteria, AIC), generalised additive models (GAM; Hastie and Tibshirani 1990) using a spline function with a degree of smoothing of 4, generalised boosting models (GBM; Ridgeway 1999; Friedman et al. 2000) with 2000 trees and random forest (RF; Brieman 2001).

As no independent data were available to evaluate the models, we used a split-sample procedure and $70 \%$ of the data (presences and pseudo-absences) were randomly chosen and used for model calibration, with $30 \%$ used for model evaluation. This procedure was repeated five times for each model type and for each of the 20 datasets of occurrence selection. For each data split, the predictive performance of the models was evaluated with two frequently used metrics: the area under the curve (AUC) of a receiver operating characteristic plot (ROC; Ogilivie and Creelman 1968) and the Boyce index (Boyce et al. 2002). The AUC varies from

0.5 (random predictions) to 1 (perfect models); a model is considered reliable with AUC higher than 0.7 (Swets 1988). The Boyce index varies between -1 (counter predictions) and 1 (perfect predictions). This index is particularly adapted for our data as it is calculated on presences only, independently of pseudo-absences (Hirzel et al. 2006).

As proposed in BioMod (Thuiller et al. 2009), the relative importance of each predictor in a model was calculated by randomising one predictor and projecting the model with the 
randomised variable while keeping the other predictors unchanged. The results of the model containing the randomised predictor were then correlated with those of the original model. The importance of the predictor was calculated as one minus this correlation (consequently, the higher the value is, the more important is the variable for the model quality). For each model and for each of the 20 datasets of occurrence selection, the calculation of predictor importance was repeated with five datasets of randomized values.

To produce the most reliable map of potential habitat, we used an ensemble forecasting, as recommended by Araújo and New (2007), with the final set of models calibrated using one of the randomly selected dataset with 214 occurrences and 10'000 weighted pseudo-absences. The results of the four models (GLM, GAM, GBM and RF) were average weighted by their respective AUC. The probabilities of presence predicted by the ensemble model were transformed into presence-absence data with an optimised threshold maximising the model sensitivity and specificity (Liu et al. 2005). The projection of the ensemble model was finally restricted to the three geological categories on which L. alpinum was most commonly observed (see the Results section).

\section{Analyses of relevés}

All the subsequent analyses of the 249 relevés were realised following the elimination of rare species ( $<3$ occurrences) and transformation of the cover indices (Braun-Blanquet 1964), as follows: $\mathrm{r}=1,+=2,1=3,2=4,3=5,4=6$ and $5=7$.

To distinguish groups of phytosociological relevés, a hierarchical clustering analysis was performed using the chord distance and Ward's minimum variance clustering method (Borcard et al. 2011). The optimal number of groups was defined according to Mantel correlation coefficients between the distance matrix and binary matrices ( 0 if relevés are in the same group, 1 otherwise) computed from the dendrogram sectioned at various levels (see the function in R given by Borcard et al. 2011, p. 71). Differential species in the groups were selected by calculating their indicator values (Dufrêne and Legendre 1997).

The ecological conditions of each group were documented by the eight ecological indicator values attributed to species by Landolt et al. (2010). The median value was calculated for each relevé and each indicator value. However, to obtain more informative values than the habitual median limited to the indicator classes, the median $\mu$ was calculated with the following formula based on the $50 \%$ value of a cumulative frequency curve (Ellenberg 1991):

$$
\mu=m+w \frac{(n / 2)-n_{m}}{n_{x}}
$$

where $m$ is the lower limit of the median class (here, the intermediate value between the median class and the previous one $), w$ is the width of the classes $(0.5$ for $\mathrm{T}$ and $\mathrm{F} ; 1$ for $\mathrm{L}, \mathrm{K}$, $\mathrm{R}$ and $\mathrm{N} ; 2$ for $\mathrm{D}$ and $\mathrm{H}$; see Table 2 for abbreviations), $n$ is the number of species in the relevé, $n_{m}$ is the number of species with an indicator value lower than the median class and $n_{x}$ is the number of species with an indicator value similar to the median class.

A principal component analysis (PCA), after a Hellinger transformation of the data (Legendre and Gallagher 2001), was computed to study the distribution of the groups along floristic gradients. The ecological indicator values (Landolt et al. 2010) were passively projected using the correlation between the median ecological values of each relevé and its scores on axes (Wohlgemuth 2000).

These analyses were computed using $\mathrm{R}$ software (R Development Team 2011) with the libraries vegan (clustering, Hellinger transformation, PCA) and labdsv (indicator values of the species). The nomenclature of the phytosociological alliances follows Delarze and Gonseth 
(2008), and the names of associations were conserved from the authors of the relevés (not all the relevés were classified).

\section{Results}

Out of the 344 available occurrences, 242 were on pure calcareous bedrocks, 49 on mixed bedrocks, 42 on ultramaphic bedrocks and 11 on base-poor bedrocks. The distribution of $L$. alpinum occurrences in relation to the ecological variables are summarized in App. 2 (supplemental archives).

\section{Species distribution models}

The evaluation values obtained for the four modelling techniques and the 20 datasets (random selection of presences) after the split-sample procedure resulted in a mean AUC value of $0.81 \pm 0.01$ and a mean Boyce index of $0.90 \pm 0.18$. The four modelling techniques and the 20 datasets produced predictions of similar quality. As predictions with AUC values were above 0.8 and Boyce index values close to 1 , models can be qualified as good and trustworthy (Araújo et al. 2005).

The most important predictor for modelling the L. alpinum distribution was the average moisture index (Fig. 1), followed by the summer temperature, the slope and the topographic position. Solar radiation was the least important predictor. The response curves of the models showed that the optimal value for the moisture index was less than $5 \mathrm{~mm} \cdot \mathrm{day}^{-1}$, which corresponds to dry conditions for the Alps (Fig. 2). The suitability of habitat increased with a decreasing mean temperature (i.e., with increasing elevation) and increasing slope.

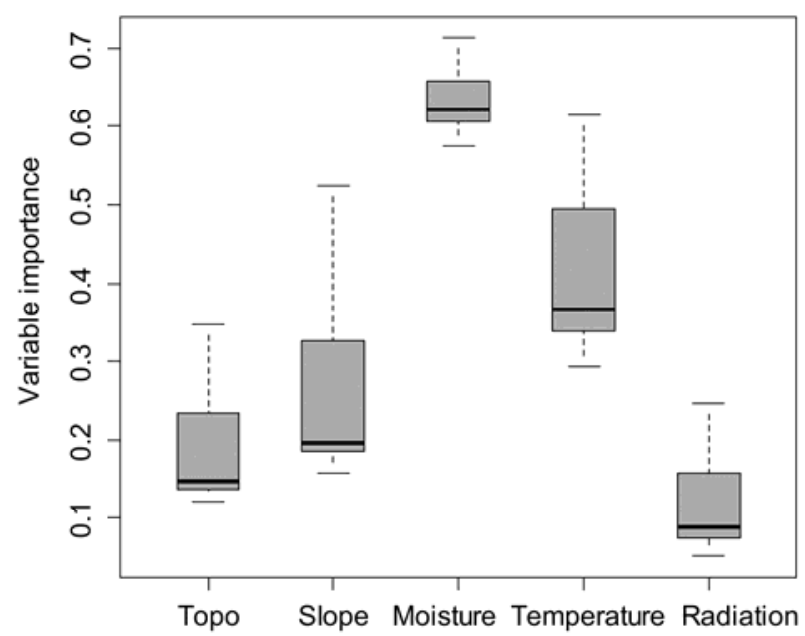

Fig. 1 Importance of each predictor used in the models: a high value (like moisture) indicates an important influence of the predictor in the models. Topo, topographic position; Slope, slope in degrees; Moisture, difference between precipitation and potential evapotranspiration over the growing season (June-August); Temperature, mean temperature for the growing season; Radiation, sum of solar radiation for the growing season.

The map of predicted potential habitats showed that the Inner Alps are the most suitable area for L. alpinum, with isolated possible regions in the Outer Alps (Fig. 3 and App. 3 in supplemental archives). In summary, typical sites where L. alpinum can grow are in dry areas, at high elevations and on steep slopes. 


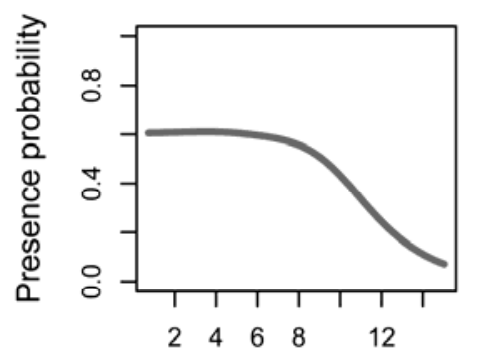

a

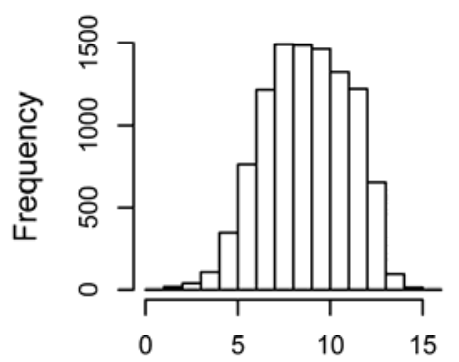

b

Temperature $\left({ }^{\circ} \mathrm{C}\right)$

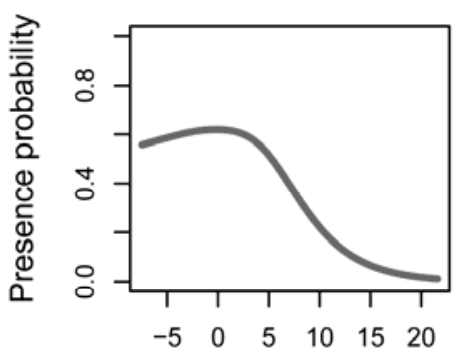

Moisture (mm / day)

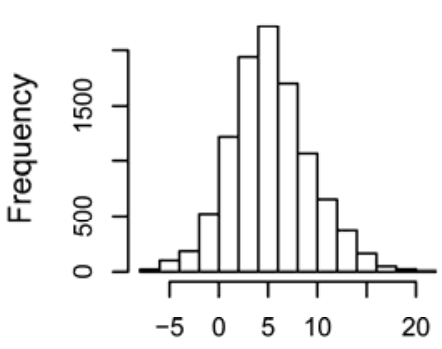

Moisture ( $\mathrm{mm} /$ day)
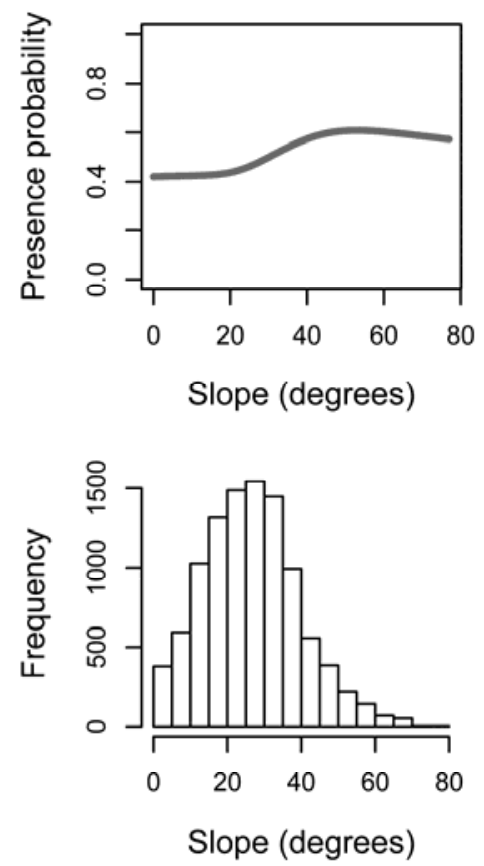

Fig. 2 (a) Response curves for Leontopodium alpinum with GAM for the three most important predictors (the response curves for the other models showed similar trends) and (b) frequency distribution of the same predictors in the Swiss Alps. See Fig. 1 for the predictor abbreviations and App. 2 for the distribution of $L$. alpinum occurrences in relation to all predictors.

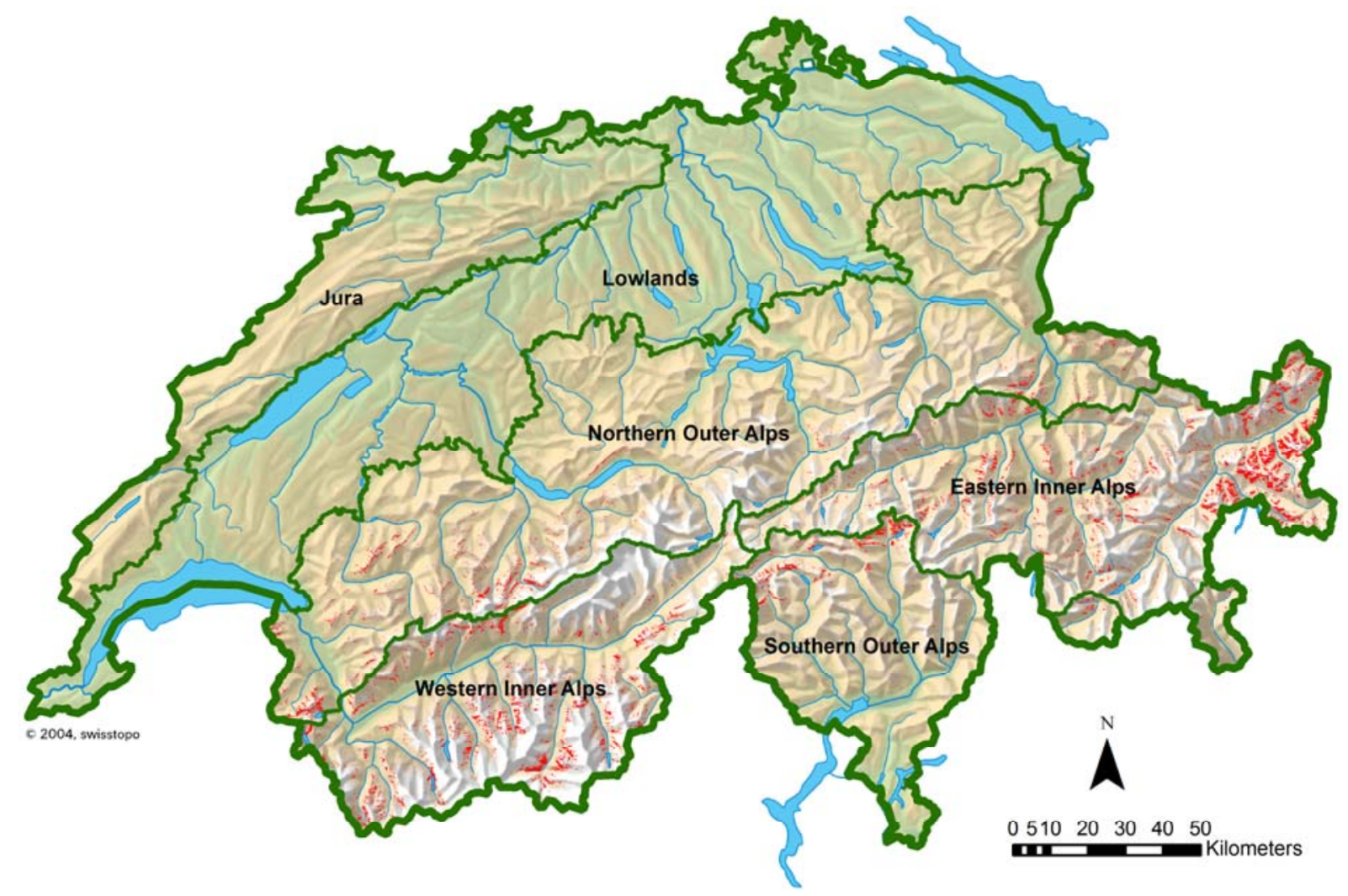

Fig. 3 Predicted habitat suitability map of Leontopodium alpinum (red areas) in the Swiss Alps (map from SwissTopo; http://www.swisstopo.admin.ch). Other colours correspond to elevation (greenish, $<600 \mathrm{~m}$ asl; beige, $600-2500 \mathrm{~m}$ asl, $>2500 \mathrm{~m}$ asl), The map can be enlarged from the App. 3 (supplemental archives). 


\section{Clustering and principal component analysis of the relevés}

The first axis of the PCA explained $10.1 \%$ of the variance, and the ecological indicator values pointed to a temperature and light gradient along this axis (Fig. 4), extending from a heliophilous pole on the left side to a thermophilic pole on the right side. The second axis explained $7.4 \%$ of the variance and was associated with a gradient of soil $\mathrm{pH}$.

Eight groups of relevés were retained in the clustering analysis (Table 1). The median ecological indicator values (Table 2) showed high ranges between the groups for soil $\mathrm{pH}$ (3.36-4.67, neutral to alkaline), soil aeration (3.16-4.40, moderate to good aeration), temperature (1.33-2.25, lower subalpine to alpine belts) and humus content (2.00-2.92, little to moderate). Moderate ranges of values were observed for the light conditions (4.09-4.81, well-lit sites to almost full light), whereas small ranges were found for humidity (moderately dry to fresh), continentality (subcontinental) and nutrient availability (infertile).

\begin{tabular}{|c|c|c|c|c|c|c|c|c|}
\hline Relevés groups & 3 & 2 & 6 & 5 & 1 & 4 & 7 & 8 \\
\hline Nbre of relevés & 13 & 33 & 63 & 30 & 38 & 30 & 29 & 13 \\
\hline \multicolumn{9}{|l|}{ Constant species } \\
\hline Leontopodium alpinum & V & V & V & V & V & $\mathrm{V}$ & V & V \\
\hline Sesleria caerulea & 1 & V & IV & V & $\mathrm{V}$ & $\|$ & $\mathrm{V}$ & V \\
\hline Festuca quadriflora & V & V & V & IV & III & III & II & III \\
\hline Minuartia verna & V & IV & IV & IV & III & II & IV & $\|$ \\
\hline Aster alpinus & 1 & IV & IV & IV & IV & III & $\mathrm{v}$ & ॥ \\
\hline Agrostis alpina & $\|$ & $\mathrm{V}$ & IV & IV & III & $\|$ & IV & $\|$ \\
\hline Elyna myosuroides & IV & $\mathrm{V}$ & $\|$ & III & 1 & I & 1 & $\mathrm{r}$ \\
\hline Galium pumilum & $r$ & $\mathrm{r}$ & IV & $\|$ & III & $r$ & III & $\mathrm{r}$ \\
\hline Gentiana verna & 1 & III & IV & $\|$ & $\|$ & ॥ & III & $r$ \\
\hline Thymus serpyllum aggr. & $r$ & ॥ & III & III & IV & IV & $\mathrm{V}$ & $\mathrm{r}$ \\
\hline Campanula cochleariifolia & II & $\mathrm{r}$ & 1 & III & ॥ & $r$ & $\mathrm{r}$ & 1 \\
\hline \multicolumn{9}{|l|}{ Differential species group 3} \\
\hline Saxifraga oppositifolia & $\mathrm{V}$ & III & ॥ & ॥ & 1 & & $r$ & \\
\hline Carex rupestris & $\mathrm{V}$ & 1 & $\mathrm{r}$ & IV & $\mathrm{r}$ & & & \\
\hline Herniaria alpina & IV & $\mathrm{r}$ & IV & ॥ & & 1 & II & \\
\hline Gentiana schleicheri & IV & 1 & III & $\|$ & & & & \\
\hline Linaria alpina s.str. & III & $\mathrm{r}$ & 1 & $\mathrm{r}$ & & & II & \\
\hline Draba dubia & III & $\mathrm{r}$ & $\mathrm{r}$ & I & & & & \\
\hline \multicolumn{9}{|l|}{ Differential species group 2} \\
\hline Polygonum viviparum & III & V & $r$ & III & III & $r$ & & ॥ \\
\hline Campanula scheuchzeri & & IV & III & ॥ & III & I & 1 & $r$ \\
\hline Arenaria ciliata & III & III & ॥ & 1 & $\mathrm{r}$ & & & $\mathrm{r}$ \\
\hline Ligusticum mutellinoides & III & III & ॥ & & $\mathrm{r}$ & $r$ & & \\
\hline Pedicularis verticillata & & III & $\mathrm{r}$ & 1 & 1 & & & $\mathrm{r}$ \\
\hline Silene acaulis & & III & $\mathrm{r}$ & $r$ & $\mathrm{r}$ & & & 1 \\
\hline \multicolumn{9}{|l|}{ Differential species group 6} \\
\hline Draba aizoides & IV & II & $\mathrm{V}$ & ॥ & 1 & II & II & \\
\hline Carex curvila s.I. & & II & IV & $\mathrm{r}$ & & 1 & & \\
\hline Sempenivum arachnoideum & $r$ & II & IV & ॥ & 1 & III & III & \\
\hline Artemisia glacialis & & & III & & $\mathrm{r}$ & III & & \\
\hline Veronica fruticans & & $\mathrm{r}$ & III & $\mathrm{r}$ & $\mathrm{r}$ & 1 & ॥I & \\
\hline Oxytropis helvetica & ॥ & & III & $\mathrm{r}$ & & & & \\
\hline \multicolumn{9}{|l|}{ Differential species group 1} \\
\hline Senecio doronicum & & $\mathrm{r}$ & III & III & $\mathrm{V}$ & II & IV & \\
\hline Carex sempenvirens & & III & $\mathrm{r}$ & III & $\mathrm{v}$ & I & 1 & $\mathrm{r}$ \\
\hline Anthyllis vulneraria subsp. alpestris & & II & 1 & ॥ & IV & 1 & ॥ & ॥ \\
\hline Festuca violacea aggr. & & $\mathrm{r}$ & II & 1 & III & $\mathrm{r}$ & 1 & \\
\hline Phyteuma orbiculare & & $\mathrm{r}$ & & & III & & & \\
\hline Scabiosa lucida & & $\mathrm{r}$ & & & III & & & \\
\hline \multicolumn{9}{|l|}{ Differential species group 7} \\
\hline Bupleurum ranunculoides s.str. & & $\mathrm{r}$ & $r$ & ॥ & 1 & III & $\mathrm{V}$ & \\
\hline Euphorbia cyparissias & & $\mathrm{r}$ & II & $\mathrm{r}$ & ॥ & ॥ & $\mathrm{V}$ & \\
\hline Carex humilis & & $\mathrm{r}$ & & 1 & II & $\mathrm{r}$ & $\mathrm{V}$ & \\
\hline Oxytropis campestris s.str. & & II & ॥ & I & $\|$ & III & IV & \\
\hline Dianthus sylvestris & & & $\mathrm{r}$ & $r$ & $\mathrm{r}$ & III & IV & \\
\hline Acinos alpinus & & $r$ & 1 & $r$ & ॥ & ॥ & IV & \\
\hline
\end{tabular}

\begin{tabular}{|c|c|c|c|c|c|c|c|c|}
\hline Relevés groups & 3 & 2 & 6 & 5 & 1 & 4 & 7 & 8 \\
\hline Nbre of relevés & 13 & 33 & 63 & 30 & 38 & 30 & 29 & 13 \\
\hline \multicolumn{9}{|c|}{ Differential species group 7 (continuation) } \\
\hline Hieracium pilosella & & & 1 & 1 & $\mathrm{r}$ & ॥ & IV & \\
\hline Koeleria macrantha & & & r & & & $\|$ & IV & \\
\hline Carlina acaulis subsp. caulescens & & $\mathrm{r}$ & $\mathrm{r}$ & I & ॥ & 1 & IV & \\
\hline Teucrium montanum & & & $r$ & I & $r$ & । & IV & $\mathrm{r}$ \\
\hline Astragalus australis & & & $\mathrm{r}$ & 1 & I & ॥ & III & \\
\hline Plantago serpentina & & & $\mathrm{r}$ & $\mathrm{r}$ & $\mathrm{r}$ & ॥ & III & \\
\hline Pulsatilla halleri & & & I & $\mathrm{r}$ & $\mathrm{r}$ & ॥ & III & \\
\hline Erysimum rhaeticum & & & $\mathrm{r}$ & & 1 & ॥ & III & \\
\hline Campanula rotundifolia & & $\mathrm{r}$ & & I & I & 1 & III & \\
\hline Trifolium montanum & & $\mathrm{r}$ & & $\mathrm{r}$ & $\mathrm{r}$ & $\mathrm{r}$ & III & \\
\hline Astragalus leontinus & & & $\mathrm{r}$ & & $\mathrm{r}$ & 1 & III & \\
\hline Briza media & & & & $\mathrm{r}$ & I & $r$ & III & \\
\hline Carex caryophyllea & & $\mathrm{r}$ & & & $\mathrm{r}$ & $\mathrm{r}$ & III & \\
\hline Galium lucidum & & & & $\mathrm{r}$ & $\mathrm{r}$ & 1 & III & \\
\hline Dactylis glomerata & & & & & & $\mathrm{r}$ & III & \\
\hline Linum catharticum & & & & & 1 & & III & \\
\hline \multicolumn{9}{|l|}{ Differential species group 8} \\
\hline Dryas octopetala & & ॥ & $\mathrm{r}$ & 1 & II & & & $\mathrm{v}$ \\
\hline Saxifraga caesia & & $\mathrm{r}$ & & 1 & $\mathrm{r}$ & & & $\mathrm{V}$ \\
\hline Carex mucronata & & & $\mathrm{r}$ & $\mathrm{r}$ & $\mathrm{r}$ & 1 & $\mathrm{r}$ & IV \\
\hline Gentiana clusii & & 1 & & 1 & II & & & IV \\
\hline Carex firma & & & & 1 & $\mathrm{r}$ & & & IV \\
\hline Crepis kerneri & & & & $\mathrm{r}$ & & & & IIII \\
\hline \multicolumn{9}{|l|}{ Other species } \\
\hline Helianthemum alpestre & & $\|$ & ॥ & IV & III & ॥ & III & $\mathrm{v}$ \\
\hline Carduus defloratus s.I. & & $r$ & 1 & 1 & IV & $\mathrm{r}$ & IV & $\mathrm{r}$ \\
\hline Galium anisophyllon & $r$ & III & IV & III & ॥ & 1 & IV & \\
\hline Euphrasia salisburgensis & & 1 & $\mathrm{r}$ & ॥ & III & $\mathrm{r}$ & ॥ & I \\
\hline Sedum atratum & III & i & I & I & $\|$ & i & & r \\
\hline Gypsophila repens & 1 & & r & III & $\|$ & 1 & III & $\mathrm{r}$ \\
\hline Euphrasia minima & I & III & ॥ & 1 & I & 1 & $\mathrm{r}$ & \\
\hline Helianthemum nummularium s.I. & & I & II & ॥ & $\mathrm{V}$ & II & $\mathrm{v}$ & \\
\hline Festuca ovina aggr. & & 1 & ॥ & ॥ & ॥ & III & IV & \\
\hline Lotus corniculatus aggr. & & $\mathrm{r}$ & 1 & 1 & III & 1 & IV & \\
\hline Cerastium arvense subsp. strictum & & $\mathrm{r}$ & III & 1 & 1 & III & ॥ & \\
\hline Gentiana campestris s.str. & & ॥ & 1 & I & III & $\mathrm{r}$ & 1 & \\
\hline Hieracium villosum & & $\mathrm{r}$ & & $\mathrm{r}$ & III & $\mathrm{r}$ & ॥ & I \\
\hline Globularia cordifolia & & $\mathrm{r}$ & & $\|$ & $\|$ & ॥ & III & ॥ \\
\hline Juniperus communis subsp. nana & & $\mathrm{r}$ & 1 & ॥ & ॥ & 1 & III & \\
\hline Silene exscapa & III & ॥ & ॥I & $\mathrm{r}$ & & 1 & & \\
\hline Euphrasia alpina & & $\mathrm{r}$ & ॥ & 1 & & ॥ & III & \\
\hline Anthyllis vulneraria subsp. valesiaca & & & III & ॥ & $\mathrm{r}$ & 1 & III & \\
\hline Leucanthemum adustum & & & & $\mathrm{r}$ & III & $\mathrm{r}$ & III & \\
\hline Mean number of species & 16.6 & 29 & 29.3 & 24.7 & 35.1 & 24.6 & 40.8 & 14.6 \\
\hline
\end{tabular}

Table 1 Synthetic table of the clustering analysis. Eight groups of relevés were retained, and the species were classified based on their indicator values for the groups. The groups are approximately ordered following axis 1 of the PCA (see Fig. 4). Only species present in at least $40 \%$ of the relevés of one group are retained in this table (see App. 5 for the complete table). Species frequency in the groups is given by the Roman numeral: V, species frequency $>80 \%$; IV, $60-80 \%$; III, 40-60\%; II, 20-40\%; I, 10-20\%; r, $<10 \%$. 
Group 3 contained the most heliophilous relevés under the coldest conditions and were situated on humus-poor soils but with good aeration (Table 2). This group was differentiated by scree and rock species (Saxifraga oppositifolia, Carex rupestris, Herniaria alpina). Previous classifications of these relevés were mainly attributed to Herniarietum alpinae Zollitsch 1968 found on screes of calcareous slates (Drabion hoppeanae). Close to this group, group 2 shared Elyna myosuroides (highest frequency in this group) with two other Elynion species (Ligusticum mutellinoides, Arenaria ciliata). This group had the most humus-rich soils. The previously classified relevés were mostly attributed to Elynetum myosuroidis Rübel 1911 (Elynion), corresponding to alpine windy ridges.

At the other extreme of the light-temperature gradient, group 7 corresponded to the warmest and least lit (densest grass cover) conditions and was differentiated by species belonging to continental steppes (Stipo-Poion: Carex humilis, Koeleria macrantha, Pulsatilla halleri, Erysimum rhaeticum) and other species from dry, thermophilous grasslands (e.g., Euphorbia cyparissias, Teucrium montanum, Dianthus sylvestris, Plantago serpentina, Galium lucidum). Almost all of these relevés are from the Zermatt region, in the Inner Alps, and were attributed to Astragalo leontini-Seslerietum Richard 1985, which is an association representing the dry, continental wing of Seslerion (Steiner 2002). Group 1 is similarly characterised by poorly lit conditions and moderate soil aeration but colder conditions. All of the differential species (Senecio doronicum, Carex sempervirens, Anthyllis vulneraria subsp. alpestris, Festuca violacea aggr.) are typical of calcareous, alpine grasslands (Seslerion). The previously classified relevés were attributed to Seslerio-Caricetum sempervirentis Br.-Bl. in Br.-Bl. et Jenny 1926, the central association of the Seslerion.

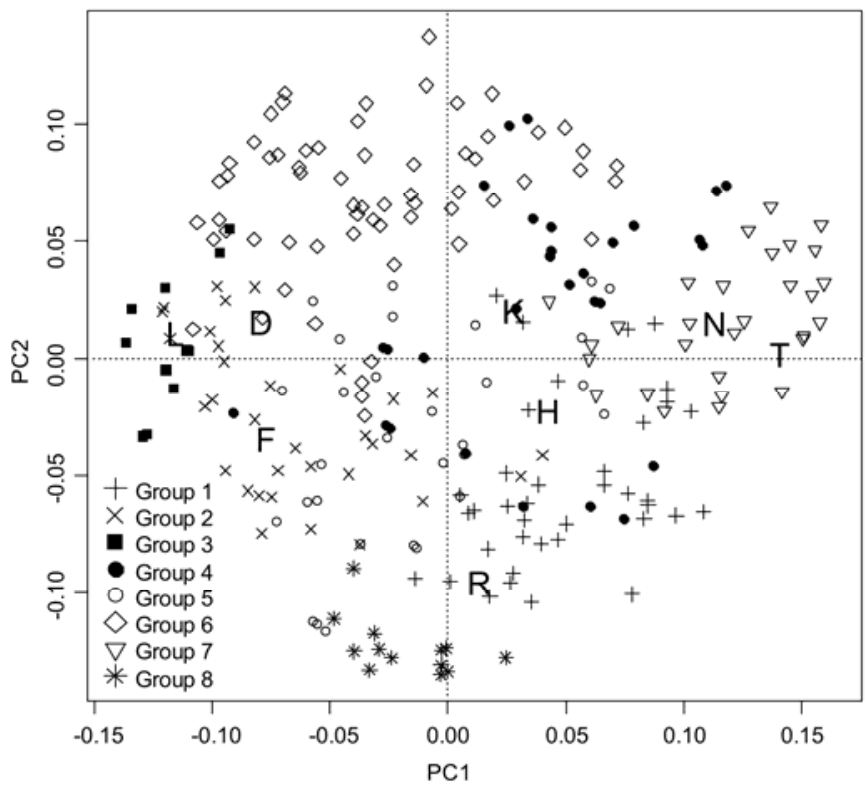

Fig. 4 Principal component analysis with passive projection of the ecological indicator values (Landolt et al. 2010) for climate factors ( $\mathrm{T}$, temperature; $\mathrm{K}$, continentality; L, light) and soil characteristics ( $\mathrm{N}$, nutrient availability; H, humus content; $\mathrm{D}$, aeration; $\mathrm{F}$, humidity; $\mathrm{R}, \mathrm{pH})$. The relevés are represented by symbols related to the groups obtained via clustering analysis (see Table 1). Axes 1 and 2 explain $10.1 \%$ and $7.4 \%$ of the variance, respectively.

The largest group (6) showed the lowest soil $\mathrm{pH}(\mathrm{R})$, corresponding to a mixture of calcicolous species (e.g., Draba aizoides, Oxytropis helvetica) and species colonising neutral to weakly acidic soils (e.g., Artemisia glacialis, Veronica fruticans). Carex curvula s.l. is problematic, as it contains an acidophilous taxon (C. curvula s.str.) and a calcicolous taxon (C. curvula subsp. rosae), though the exact taxon was not always indicated. However, 38 of the 39 precisely identified occurrences were C. curvula subsp. rosae. Three-quarters of the 
relevés were previously attributed to Artemisio glacialis-Festucetum pumilae Richard 1985, a pioneer association of Seslerion on little-developed soils, rich in gravel and sand, partly unstable, in the Inner Alps (Steiner 2002), whereas one-quarter was attributed to Elynetum myosuroidis.

Groups 4 and 5 presented intermediate compositions, without any frequent differential species and showing median ecological values mostly around the middle of the ranges (Table 2). The relevés were previously attributed to various associations: Artemisio glacialisFestucetum pumilae, Seslerio-Caricetum sempervirentis, Androsacetum alpinae Br.-B1. 1918 (fine screes of siliceous or ultramafic rocks, in Androsacion alpinae), Caricetum fimbriatae Richard 1985 (screes of ultramaphic rocks, in Caricion curvulae), Androsacetum helveticae Br.-B1. in Br.-B1. et Jenny 1926 (alpine calcareous cliffs, in Potentillion caulescentis) or Potentillo caulescentis-Hieracietum humilis Br.-Bl. 1933 (montane-subalpine calcareous cliffs, in Potentillion caulescentis). All these associations are linked to rocky conditions, with a low vegetation cover.

\begin{tabular}{lcccccccc}
\hline Relevé group & 3 & 2 & 6 & 5 & 1 & 4 & 7 & 8 \\
\hline Climate & & & & & & & & \\
$\quad$ T (temperature) & 1.33 & 1.55 & 1.57 & 1.73 & 1.88 & 1.89 & $\mathbf{2 . 2 5}$ & 1.63 \\
L (light) & $\mathbf{4 . 8 1}$ & 4.41 & 4.50 & 4.41 & 4.09 & 4.32 & 4.09 & 4.67 \\
K (continentality) & 3.85 & 3.61 & 3.78 & 3.77 & 3.59 & $\mathbf{3 . 8 7}$ & 3.83 & 3.82 \\
Soil & & & & & & & & \\
R (pH) & 3.64 & 3.43 & 3.36 & 3.83 & 3.84 & 3.48 & 3.53 & $\mathbf{4 . 6 7}$ \\
D (aeration) & $\mathbf{4 . 4 0}$ & 3.38 & 3.71 & 3.54 & 3.16 & 3.74 & 3.18 & 4.00 \\
H (humus content) & 2.00 & $\mathbf{2 . 9 2}$ & 2.71 & 2.74 & 2.87 & 2.65 & 2.82 & 2.73 \\
F (humidity) & $\mathbf{2 . 5 0}$ & 2.40 & 2.18 & 2.16 & 2.29 & 2.01 & 2.06 & 2.15 \\
N (nutrient availability) & 1.80 & 1.92 & 1.98 & 1.93 & $\mathbf{2 . 0 7}$ & 2.00 & 2.04 & 1.92 \\
\hline
\end{tabular}

Table 2 Median ecological indicator values (Landolt et al. 2010) of the groups of relevés. The groups are ordered following axis 1 of the PCA (Fig. 4). The highest value of each indicator is in bold and the lowest in italics.

Lastly, group 8 was separated along the second axis of the PCA (Fig. 4) and was characterised by the highest soil $\mathrm{pH}$ and was differentiated by six species found on rocky, open grasslands on limestone (Dryas octopetala, Saxifraga caesia, Carex mucronata, Gentiana clusii, Carex firma, Crepis kerneri). All of the previously classified relevés were attributed to Caricetum firmae Rübel 1911, with rocky, calcareous grasslands in the alpine belt (Caricion firmae).

In summary, L. alpinum was observed in a broad range of phytosociological alliances (see App. 4, supplemental archives), all corresponding to subalpine-alpine communities on baserich bedrocks, with a low to very low grass cover, on nutrient-poor, dry to fresh soils, among apparent rocks or on ridges.

\section{Discussion}

\section{Significance of the results}

In this study, we investigated the autecology of Leontopodium alpinum to obtain a better understanding of its distribution in the Swiss Alps. The collected relevés were realised by different authors within the context of vegetation studies, mainly aiming to classify plant communities. Hence, we can consider them not to be biased toward particular conditions 
linked to L. alpinum growth. However, there is a regional bias, as approximately half of the 249 available relevés were from the Zermatt region, which is a particularly interesting region for flora and plant communities and has been extensively investigated (Richard 1991; Steiner 2002). Nevertheless, the other available relevés are well distributed throughout the Swiss Alps, including the Outer Alps; altogether, they likely represent most of the ecological range of the species in Switzerland.

\section{Ecological conditions for $L$. alpinum}

As indicated in previous descriptions (Wagenitz 1979; Oberdorfer and Müller 1990), L. alpinum was mostly observed on limestone, with $85 \%$ of the occurrences on pure calcareous bedrocks or on mixtures containing limestone (e.g., moraines). However, other basic cations can replace calcium, as $12 \%$ of the observations were on ultramaphic bedrocks, previously only mentioned by Wagenitz (1979). Conversely, the species avoids siliceous bedrocks, with only $3 \%$ of the occurrences, whereas this type of rocks represents $39 \%$ of the Swiss Alps above $1300 \mathrm{~m}$ asl. As contamination by closely located limestone cannot be excluded for some of these rare occurrences, the proportion of occurrences on siliceous rocks is certainly lower. A soil map would have probably given better results in the models. The high median ecological indicator value for soil $\mathrm{pH}(\mathrm{R})$ for all the groups of relevés (Table 2) confirmed the geological observations. However, this indicator also showed the highest variation among the groups, extending from weakly acid to alkaline soils. This corresponds to the $\mathrm{pH}$ of 5.5-8 reported by Rey et al. (2011) and indicates that the soil is consistently base-rich but can be completely decarbonated.

Another constant factor for all the relevés is the low grass cover, with only communities of open grasslands. L. alpinum is a light-demanding species (Wagenitz 1979), with most of the leaves in a rosette on the ground, and it most likely does not tolerate competition by other species. The importance of light at the ground level is shown by the constant species (Table 1; Sesleria caerulea, Festuca quadriflora, Minuartia verna, Aster alpinus and Agrostis alpina), which are all heliophilous (Landolt et al. 2010), and by the median ecological value for light above 4 (well lit to full light) for all the groups of relevés. This low grass cover is provided by rocky conditions, sometimes in pioneer communities on slightly unstable screes, or by other harsh conditions limiting plant growth (see below). Although the species is indicated as growing in sunny conditions (Oberdorfer and Müller 1990), solar radiation was not important as a predictor in the models, which most likely means that the aspect alone is not a constraint, with some stands occurring on a north aspect, and that a south-facing slope may be a way to limit plant growth through dry conditions.

Indeed, the most important predictor in the models was a low moisture index, translating into a preference for regions with an approximate balance between rainfall and potential evapotranspiration or event with a water deficit. In Switzerland, this corresponds to the subcontinental climate of the Inner Alps, as indicated by Rey et al. (2011), though the species is present in wetter regions as well. This finding is in agreement with the median ecological indicator values for continentality ( $\mathrm{K}$, subcontinental climate) and for soil humidity $(\mathrm{F})$, ranging between moderately dry to fresh. Previously, Wagenitz (1979) characterised soil humidity for L. alpinum as relatively dry. The moderate to good aeration of the soil (indicator value $\mathrm{D}$ ) can be considered to be a contribution to the good water drainage.

Temperature was the second most important predictor in the models, with a higher suitability for mean summer temperatures below $10^{\circ} \mathrm{C}$, corresponding approximately to elevations $>2000 \mathrm{~m}$ asl. This preference for high elevations has long been clear, though some isolated observations in lowlands have been reported (e.g., $220 \mathrm{~m}$ asl in Slovenia and $470 \mathrm{~m}$ in a Swiss wetland; Wagenitz 1979; Rey et al. 2011). In addition, L. alpinum can grow with highly thermophilous species (e.g., Galium lucidum, Astragalus monspessulanus and Phleum 
phleoides which optimally grow in the warm colline belt; Landolt et al. 2010), and is cultivated in the montane belt. This could indicate that low temperatures are not essential for this species, but indirectly help by limiting competition. The fundamental niche of L. alpinum related to the temperature gradient is probably much larger than its realized niche.

L. alpinum has the reputation to grow in sites that are not easily accessible, on cliffs or steep slopes. However, slope had a low importance in models and its reputation is certainly overrated, with some large populations still easily accessible on weak slopes, although far away from villages. Wagenitz (1979) and Rey et al. (2011) indicated that this distribution corresponds to the populations remaining after decades of over-collection for the tourism market, but cliffs and steep slopes could also be helpful to restrict competition by providing dryer conditions and continuous erosion.

Overall, the projection of the ensemble model predicted the suitable habitat (realized niche; Jiménez-Valverde et al. 2008) of L. alpinum to mainly fall within the Inner Alps, with only isolated potentially favourable regions occurring in the Northern and Southern Outer Alps, though limestone is by far the dominant bedrock in the Northern Outer Alps. In complement, the community analysis showed that the most important factor for the growth of this plant is certainly the light at the ground level, corresponding to grasslands with low plant cover. Growth under subcontinental, dry conditions (Rey et al. 2011), with summer-warm temperatures (Wagenitz 1979), is most likely an efficient way for L. alpinum to limit competition with taller species, whereas the Outer Alps, with their abundant rainfalls and denser grasslands, are less favourable. Oligotrophic soils (all groups with a low ecological value for $\mathrm{N}$ ), high elevations, dry southern aspect, steep slopes, raw soils or windy ridges, where species have to withstand very cold conditions because of the absence of snow in winter (Vonlanthen et al. 2006), are other complementary or substitute stressful conditions that limit competition. However, the importance of base-rich bedrocks and soils is less clear and could be interpreted as a supplementary factor reducing plant growth and, hence, competition with other species because of the limited availability of many essential cations (Duchaufour 1995) and the often strong drainage on limestone. However, base-rich conditions are most likely physiologically necessary for L. alpinum. Indeed, Wagenitz (1979) stated that the species was never found on strong acidic silicate bedrocks, and none of the available relevés were from siliceous cliffs or other acidophilous, dry grasslands, though some are open communities. The physiological relationship ought to be investigated in future studies.

\section{Limits due to available data}

In mountains, micro-topography is very important to explain species distribution, because it strongly influences wind, water and snow distribution (Körner 2003). Hence, the use of climatic and topographic predictors at a $25-\mathrm{m}$ resolution could bias the models, compared to direct field measurements. However, we can be quite confident that this weak resolution did not strongly modify results, as SDMs and indicator values, calculated at the plot level, converged to the same important ecological factors.

Another possible limit is related to the past decline of the species due to over-collection. As it was probably collected at the most easily accessible places (Wagenitz 1979; Rey et al. 2011), the present distribution does not reflect completely its realized niche. This may have biased our models towards too restrictive models for topography (i.e. L. alpinum grows potentially in a broader range of conditions), summer temperature (i.e. presence at lower elevations) and slope (i.e. presence on weaker slopes). But topography was already a weak predictor, the species was historically mostly located in high elevation, weak slopes correspond generally to dense grass cover, what does not fit with the other results, and our dataset included many easily accessible locations as well. 


\section{Conclusions and perspectives}

This study allowed us to obtain a description of the ecological requirements of Leontopodium alpinum, mostly confirming the previous, empirical descriptions of its autecology, yet helping to prioritise the different ecological factors. The two essential factors are a considerable amount of light at the ground level and a base-rich soil. As a short-statured, light-demanding species, L. alpinum does not withstand competition from other species. All the other ecological characteristics can be interpreted as ways to limit competition by stressful conditions (e.g., high elevations, windy ridges, southern aspect, steep slopes, oligotrophic soils, rocks and cliffs, dry substrates). The different possible combinations of these conditions result in a broad range of plant communities in which $L$. alpinum can grow. Some of them, such as screes of the Drabion hoppeanae and Androsacion alpinae, where not mentioned previously in the literature.

The projection of the models pointed to many potential areas for L. alpinum in the Swiss Alps. However, based on our experience, we know that not all of these areas are colonised. A part of the difference is certainly due to insufficiently precise predictors for modelling the exact species requirements. But supplementary investigations and monitoring would be necessary to evaluate if the species is rarer now than originally and if populations are really decreasing. Previous over-collection certainly modified its distribution in the past, but recent developments in the Alps, such as the marked increase of sheep herds (FSO 2010), and possible recruitment limitations due to poor seed production, dispersal capacities or establishment rate need to be addressed as potential causes for rarity. Limited regeneration and dispersal (Handel-Mazzetti 1927) could be an important problem in the middle to long term when considering the scattered distribution of this species and future climate change (IPCC 2007).

\section{Acknowledgements}

We thank Info Flora and Martin Schütz from the Forschungsanstalt für Wald, Schnee und Landschaft (WSL) for providing data and "Fondation Dr Ignace Mariétan" and Weleda for partial funding. We are very grateful to Antoine Guisan for helpful advice regarding the modelling techniques and Tomas Herben and two anonymous reviewers for their useful comments on an earlier draft of the manuscript.

\section{References}

Aeschimann D, Lauber K, Moser DM, Theurillat J-P (2004) Flora alpina. Belin, Paris

Araújo MB, Pearson RG, Thuiller W, Erhard M (2005) Validation of species-climate impact models under climate change. Global Change Biol 11:1504-1513

Araújo MB, New M (2007) Ensemble forecasting of species distributions. TRENDS Ecol Evol 22:42-47

Arlettaz R, Schaub M, Fournier J, Reichlin TS, Sierro A, Watson JEM., Braunisch V (2010) From publications to public action: when conservation biologists bridge the gap between research and implementation. BioScience 60:835-842

Barbet-Massin M, Jiguet F, Albert CH, Thuiller W (2012) Selecting pseudo-absences for species distribution models: how, where and how many? Methods Ecol Evol 3:327338

Blöch C, Dickoré WB, Samuel R, Stuessy TF (2010) Molecular phylogeny of the Edelweiss (Leontopodium, Asteraceae - Gnaphalieae). Edinburgh J Bot 67:235-264 
Borcard D, Gillet F, Legendre P (2011) Numerical ecology with R. Springer, New York

Boyce MS, Vernier PR, Nielsen SE, Schmiegelow FKA (2002) Evaluating resource selection functions. Ecol Model 157:281-300

Braun-Blanquet J (1964) Pflanzensoziologie. Grundzüge der Vegetationskunde. Ed. 3, Springer, Wien - New-York

Braun-Blanquet J (1969) Die Pflanzengesellschaften der rätischen Alpen im Rahmen ihrer Gesamtverbreitung. I. Teil. Bischofberger \& Co, Chur

Brieman L (2001) Random Forests. Mach learn 45:5-32

Carron C-A, Previdoli S, Baroffio C (2007) Helvetia, une nouvelle variété d'edelweiss issue d'hybrides de clones. Rev suisse Vitic Arboric Hortic 39:125-130

Deil U (2005) A review on habitats, plant traits and vegetation of ephemeral wetlands - a global perspective. Phytocoenologia 35:533-706

Delarze R, Gonseth Y (2008) Guide des milieux naturels de Suisse. Ecologie, menaces, espèces caractéristiques. Rossolis, Bussigny

Dobner MJ, Schwaiger S, Jenewein IH, Stuppner H (2003) Antibacterial activity of Leontopodium alpinum (Edelweiss). J Ethnopharmacol 89:303-301

Dobner MJ, Sosa S, Schwaiger S, Altinier G, Loggia RD, Kaneider NC, Stuppner H (2004) Anti-inflammatory activity of Leontopodium alpinum and its constituents. Planta Med $70: 502-508$

Duchaufour P (1995) Pédologie. Sol, végétation, environnement. Ed 4, Masson, Paris

Dufrêne M, Legendre P (1997) Species assemblages and indicator species: the need for a flexible asymmetrical approach. Ecol Monogr 67:345-366

Dweck AC (2004) A review of Edelweiss. SÖFW-Journal 130:65-68

Elith J, Leathwick JR (2009) Species Distribution Models: ecological explanation and prediction across space and time. Annu Rev Ecol Evol S 40:677-697

Ellenberg H (1991) Zeigerwerte der Gefässpflanzen (ohne Rubus). In Ellenberg H, Weber HE, Düll R, Wirth V, Werner W, Paulissen D (eds) Zeigerwerte von Pflanzen in Mitteleuropa. Scripta Geobotanica 18. Erich Golze KG, Göttingen, pp 9-166

Engler R, Guisan A, Rechsteiner L (2004) An improved approach for predicting the distribution of rare and endangered species from occurrence and pseudo-absence data. J Appl Ecol 41:263-274

Erhardt A (1993) Pollination of edelweiss, Leontopodium alpinum. Bot J Linn Soc 111:229240

Friedman J, Hastie T, Tibshirani R (2000) Additive logistic regression: A statistical view of boosting - Rejoinder. Ann Stat 28:400-407

FSO (2010) Agriculture Suisse - Statistique de poche 2010. Swiss Federal Statistical Office, Bern

Galland P (1982) Etude de la végétation des pelouses alpines au Parc national suisse. $\mathrm{PhD}$ thesis, Université de Neuchâtel, Neuchâtel

Guisan A, Zimmermann NE (2000) Predictive habitat distribution models in ecology. Ecol Model 135:147-186

Handel-Mazzetti H (1927) Systematische Monographie der Gattung Leontopodium. Beihefte zum Botanischen Centralblatt 44:1-178

Hastie TJ, Tibshirani R (1990) Generalized additive models. Chapman and Hall, London

Hirzel AH, Le Lay G, Helfer V, Randin C, Guisan A (2006) Evaluating the ability of habitat suitability models to predict species presences. Ecol Model 199:142-152

IPCC (2007) Summary for Policymakers. In Solomon S et al (eds) Climate Change 2007: The Physical Science Basis. Contribution of Working Group I to the Fourth Assessment Report of the Intergovernmental Panel on Climate Change. Cambridge University Press, Cambridge 
Jean L (1947) Fleurs des Alpes. Ophrys, Paris

Jiménez-Valverde A, Lobo JM, Hortal J (2008) Not as good as they seem: the importance of concepts in species distribution modelling. Divers \& Distrib 14: 885-890

Körner C (2003) Alpine plant life. Springer, Berlin

Landolt E, Bäumler B, Erhardt A, Hegg O, Klötzli F, Lämmler W et al (2010) Flora Indicativa. Haupt Verlag, Berne

Le Lay G, Engler R, Franc E, Guisan A (2010) Prospective sampling based on model ensembles improves the detection of rare species. Ecography 33:1015-1027

Legendre P, Gallagher ED (2001) Ecologically meaningful transformations for ordination of species data. Oecologia 129:271-280

Liu CR, Berry PM, Dawson TP, Pearson RG (2005) Selecting thresholds of occurrence in the prediction of species distributions. Ecography 28:385-393

McCullagh P, Nelder JA (1989) Generalized Linear Models. Ed. 2, Chapman \& Hall, London

Moser D, Gygax A, Bäumler B, Wyler N, Palese R (2002) Liste rouge des fougères et plantes à fleurs menacées de Suisse. Office fédéral de l'environnement, des forêts et $\mathrm{du}$ paysage, Centre du Réseau suisse de floristique, Conservatoire et Jardin botanique de la Ville de Genève, Bern, Chambésy

Oberdorfer E, Müller T (1990) Pflanzensoziologische Exkursionsflora. Ulmer, Stuttgart

Ogilivie JC, Creelman CD (1968) Maximum-likelihood estimation of receiver operating characteristic curve parameters. J Math Psychol 5:377-391

Randin CF, Engler R, Pearman PB, Vittoz P, Guisan A (2010) Using georeferenced databases to assess the effect of climate change on alpine plant species and diversity. In Spehn E, Körner C (eds) Data mining for global trends in mountain biodiversity. CRC Press, Taylor \& Francis Group, Boca Raton, pp 149-163

Reinalter R (2004) Zur Flora der Sedimentgebiete im Umkreis der Südrätischen Alpen, Livignasco, Bormiese und Engiadin'Ota (Schweiz-Italien). Birkhäuser, Basel

R Development Core Team (2011) R: A language and environment for statistical computing. $\mathrm{R}$ Foundation for Statistical Computing, Vienna

Rey C, Rey S, Baroffio C, Vouillamoz JF, Roguet D (2011) Edelweiss, reine des fleurs. Ed. du Belvédère, Fleurier

Richard J-L (1991) Flore et végétation de Zermatt (VS): premier aperçu et réflexions. Bull Murith 109:27-40

Ridgeway G (1999) The state of boosting. Comput Sci Stat 31:172-181

Schaminée JHJ, Hennekens SM, Chytry M, Rodwell JS (2009) Vegetation-plot data and databases in Europe: an overview. Preslia 81:173-185

Sigg P (2008) Culture de l'edelweiss pour la fleur coupée. Rev suisse Vitic Arboric Hortic 40:349-356

Speroni E et al. (2006) In vivo efficacy of different extracts of Edelweiss (Leontopodium alpinum Cass.) in animal models. J Ethnopharmacol 105:421-426

Steiner A (2002) Die Vegetation der Gemeinde Zermatt. Geobotanica Helvetica 74:1-204

Swets JA (1988) Measuring the accuracy of diagnostic systems. Science 240:1285-1293

Thuiller W, Lafourcade B., Engler R, Araújo M.B. (2009) BIOMOD - a platform for ensemble forecasting of species distributions. Ecography 32:369-373.

Vittoz P, Wyss T, Gobat J-M (2006) Ecological conditions for Saxifraga hirculus in Central Europe: A better understanding for a good protection. Biol Conserv 131:594-608

Vonlanthen CM, Bühler A, Veit H, Kammer PM, Eugster W (2006) Alpine plant communities: a statistical assessment of their relation to microclimatological, pedological, geomorphological, and other factors. Phys Geogr 27:137-154

Wagenitz G (1979) Compositae I: Allgemeiner Teil, Eupatorium-Achillea. In Hegi G, Conert HJ, Hamann U, Schultze-Motel W, Wagenitz G (eds) Illustrierte Flora von 
Mitteleuropa. Band VI, Angiospermae Dicotyledones 4, Teil 3. Ed. 2, Paul Parey, Berlin, pp 133-136

Wisz MS, Guisan A (2009) Do pseudo-absence selection strategies influence species distribution models and their predictions? An information-theoretic approach based on simulated data. BMC Ecology 9:8

Wohlgemuth $\mathrm{T}$ (2000) Diskreter und kontinuierlicher Charakter der Vegetation Waldvegetationsdaten als Referenz. Bauhinia 14:67-88

Zimmermann NE, Edwards TC, Moisen GG, Frescino TS, Blackard JA (2007) Remote sensing-based predictors improve distribution models of rare, early successional and broadleaf tree species in Utah. J Appl Ecol 44:1057-1067

Zimmermann NE, Kienast F (1999) Predictive mapping of alpine grasslands in Switzerland: species versus community approach. J Veg Sci 10:469-482 


\section{Electronic Supplementary Material}

Appendix 1 Distances between pairs of occurrences in the original data file (left) and after disaggregation (right) to avoid autocorrelation, with minimal distances of $250 \mathrm{~m}$ between occurrences. The second line shows the same data but with an enlargement between 0 and 5 km (vertical scales different)
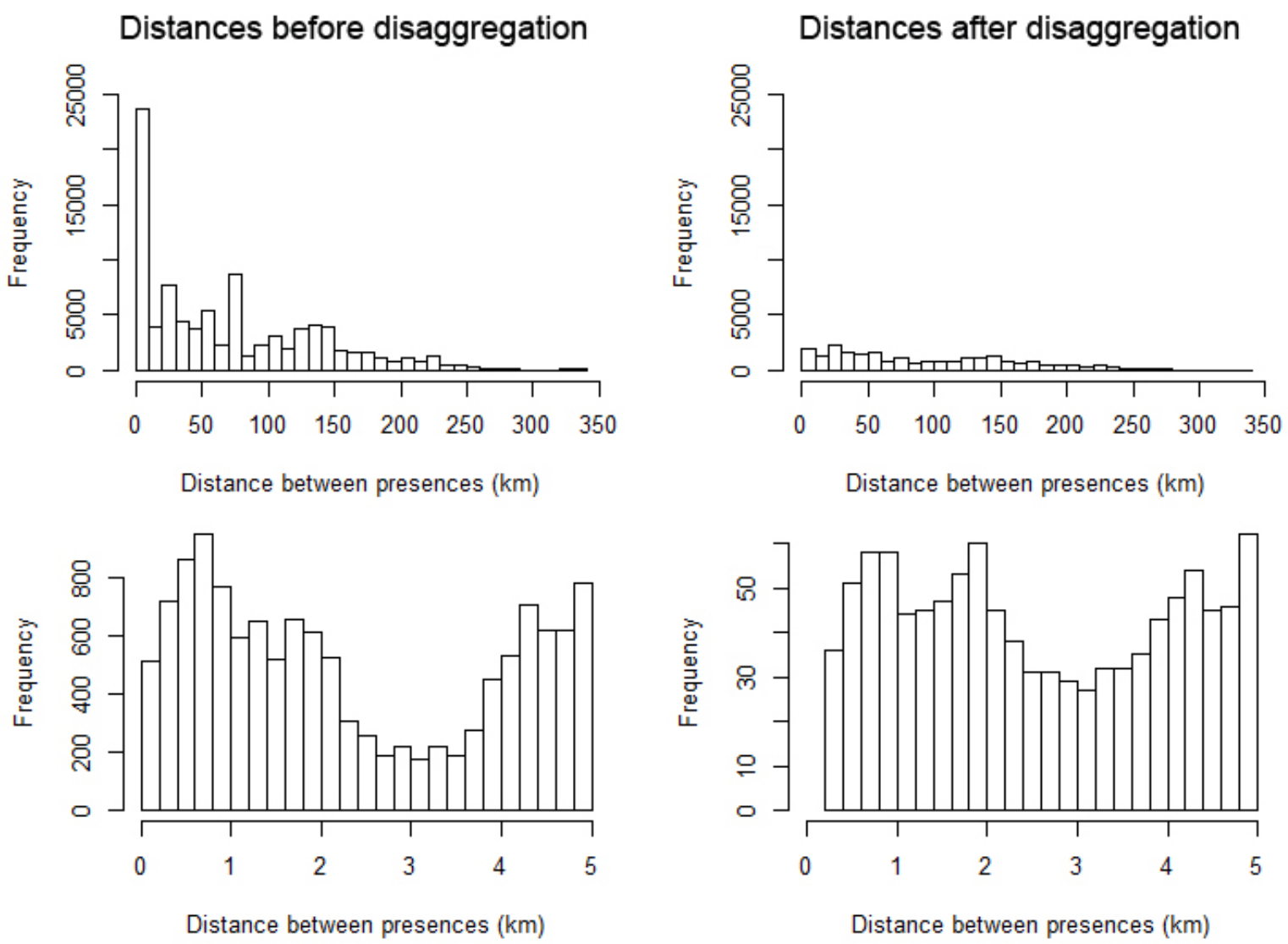
Appendix 2 Distribution of $L$. alpinum occurrences (third row) in relation to the distribution of the ecological predictors in the Alps (second row) and the response curves obtained with GAM (first row) for all predictors
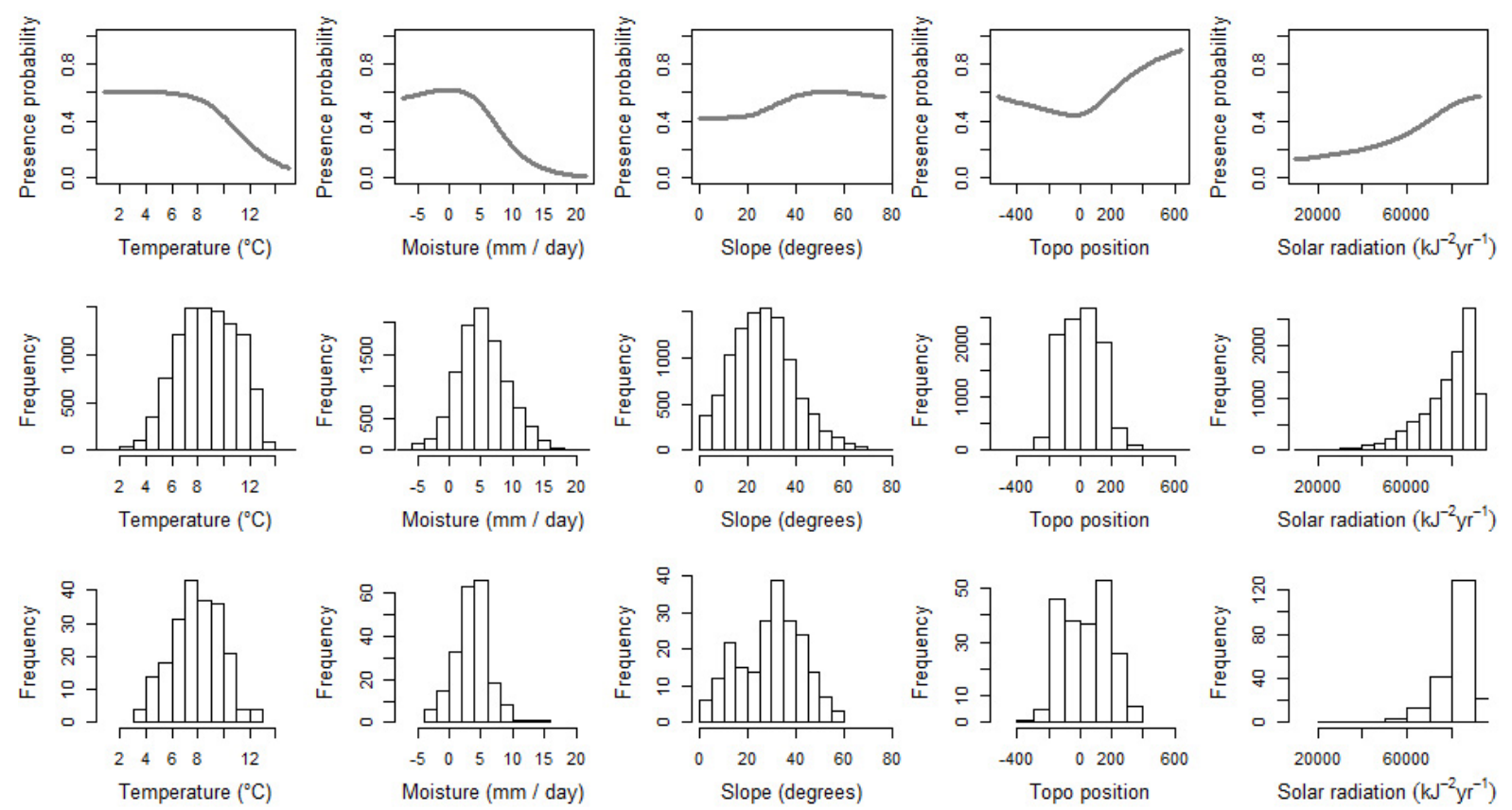

Distribution of L. alpinum occurrences (left) and distribution of pixels in the Alps (right) in relation to geology
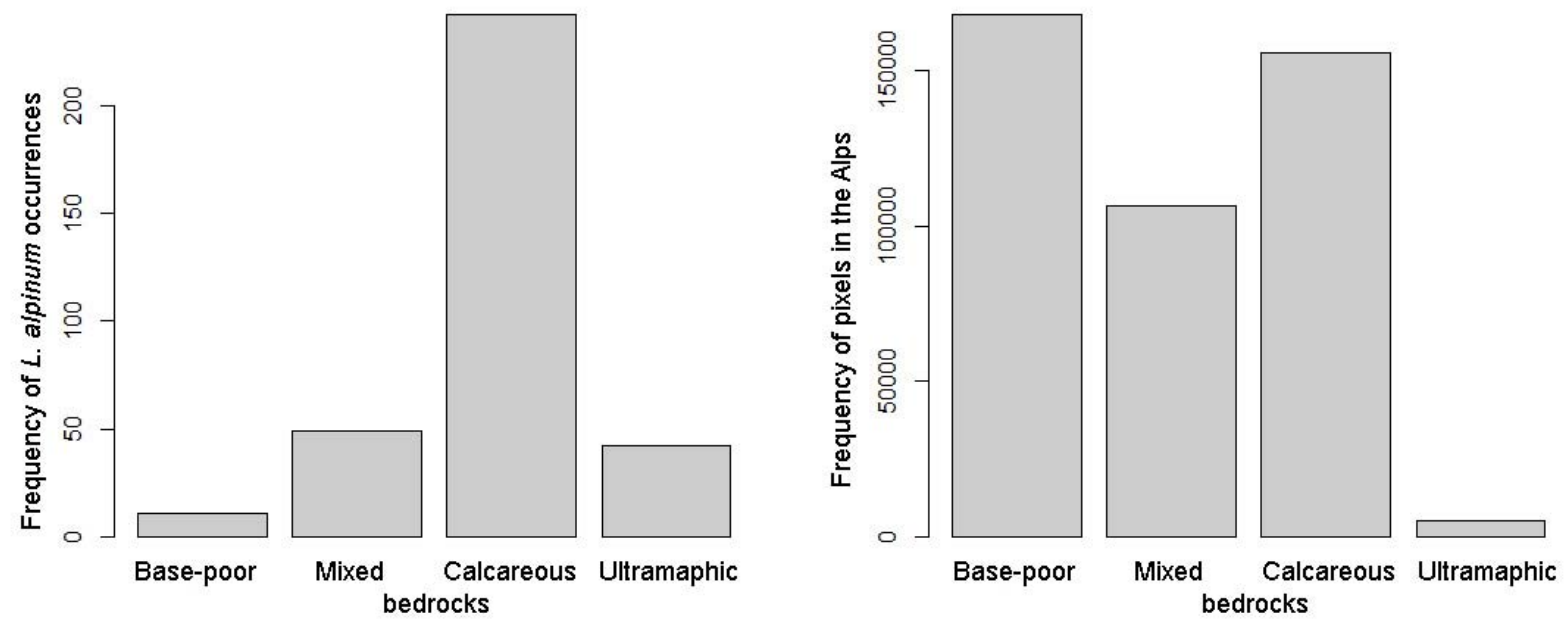
Appendix 3 Distribution of L. alpinum occurrences used in the models (red dots on the upper map) and predicted habitat suitability map (red pixels on the lower map) in the Swiss Alps (map from SwissTopo; www.swisstopo.admin.ch)
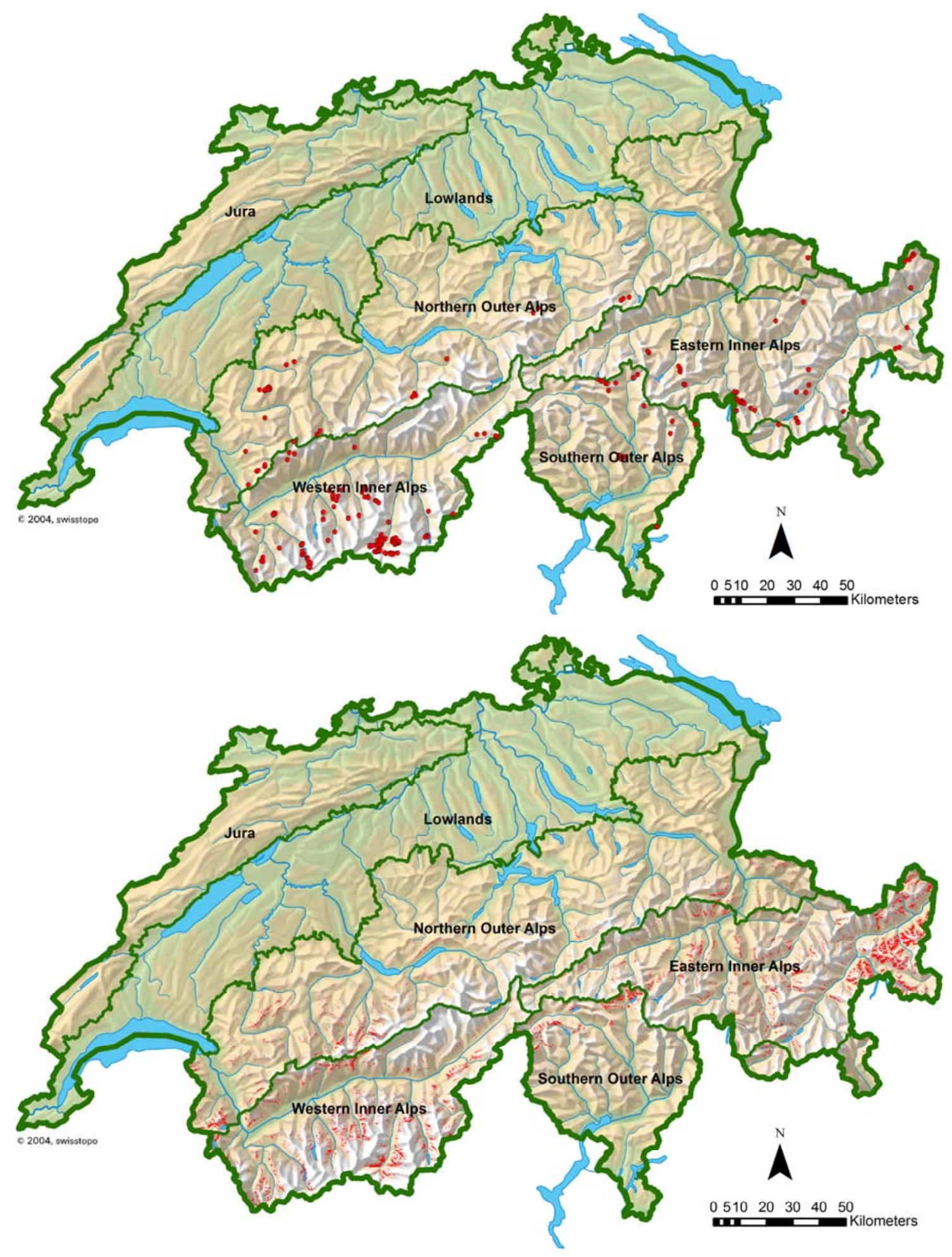
Appendix 4 Overview of the phytosociological alliances in which L. alpinum occurred in the Swiss Alps, their main ecological characteristics (mainly from Delarze and Gonseth 2008; Steiner 2002) and the associations in which L. alpinum was observed, as classified by the authors of the relevés

\begin{tabular}{|c|c|c|c|c|c|}
\hline Alliance & Substrate & Elevation [m a.s.l.] & $\begin{array}{l}\text { Other ecological } \\
\text { characteristics }\end{array}$ & pH & Associations with L. alpinum \\
\hline Seslerion & $\begin{array}{l}\text { Rocky soil, often rich in } \\
\text { fine particles, on limestone } \\
\text { or dolomite }\end{array}$ & $(1,000-) 1,500-2,500(-2,800)$ & $\begin{array}{l}\text { Dry, mainly on southern } \\
\text { aspect }\end{array}$ & Basic & $\begin{array}{l}\text { Seslerio-Caricetum sempervirentis; } \\
\text { Astragalo leontini-Seslerietum; } \\
\text { Artemisio glacialis-Festucetum pumilae }\end{array}$ \\
\hline Elynion & $\begin{array}{l}\text { Basic soil, rich in fine } \\
\text { particles, mostly on } \\
\text { limestone }\end{array}$ & $2,200-3,000$ & $\begin{array}{l}\text { Windy ridges, with low } \\
\text { snow cover in winter }\end{array}$ & Neutro-basic & Elynetum myosuroidis \\
\hline Caricion firmae & $\begin{array}{l}\text { Very shallow, rocky soil, } \\
\text { poor in fine particles, on } \\
\text { limestone or dolomite }\end{array}$ & $(1,700-) 2,300-2,800(-3,000)$ & $\begin{array}{l}\text { Dry, with a short snow } \\
\text { cover and a strong } \\
\text { influence of frost }\end{array}$ & Neutro-basic & Caricetum firmae \\
\hline Potentillion caulescentis & $\begin{array}{l}\text { Calcareous or dolomitic } \\
\text { cliffs }\end{array}$ & $(300-) 1,200-2,000(-2,800)$ & $\begin{array}{l}\text { Dry, mainly on southern } \\
\text { aspect }\end{array}$ & Basic & Androsacetum helveticae \\
\hline Drabion hoppeanae & $\begin{array}{l}\text { Calcareous, schistose and } \\
\text { fine screes }\end{array}$ & $(2,000-) 2,300-3,000$ & & Neutro-basic & Herniaretum alpinae \\
\hline Androsacion alpinae & $\begin{array}{l}\text { Fine screes on siliceous or } \\
\text { ultramafhic rocks, often } \\
\text { rich in fine particles }\end{array}$ & $(1,600-) 2,000-2,600(-3,000)$ & $\begin{array}{l}\text { L. alpinum is restricted } \\
\text { to ultramafic rocks }\end{array}$ & $\begin{array}{l}\text { Slightly to } \\
\text { stongly acid }\end{array}$ & Androsacetum alpinae \\
\hline Caricion curvulae & $\begin{array}{l}\text { Acid, often humus rich soil, } \\
\text { on siliceous or ultramafic } \\
\text { rocks }\end{array}$ & $2,200-3,300$ & $\begin{array}{l}\text { L. alpinum is restricted } \\
\text { to ultramafic rocks }\end{array}$ & $\begin{array}{l}\text { Slightly to } \\
\text { stongly acid }\end{array}$ & Caricetum fimbriatae \\
\hline
\end{tabular}


Appendix 5 Synthetic table based on the results of the clustering analysis. Eight groups of relevés were retained. They are approximately ordered following axis 1 of the PCA (see Fig. 4). Species frequency in the groups is given by Roman numeral: $\mathrm{V}$ - species frequency $>80 \%$; IV - 60-80 \%; III - 40-60\%; II - 20-40\%; I - 10-20\%; r - <10\%. The phytosociological classification of the species is according to Delarze and Gonseth (2008) at the alliance level

\begin{tabular}{|c|c|c|c|c|c|c|c|c|c|}
\hline Relevés groups & $\begin{array}{l}\text { Phytosociological } \\
\text { classification }\end{array}$ & 3 & 2 & 6 & 5 & 1 & 4 & 7 & 8 \\
\hline No of relevés & & 13 & 33 & 63 & 30 & 38 & 30 & 29 & 13 \\
\hline \multicolumn{10}{|l|}{ Constant species } \\
\hline Leontopodium alpinum & Seslerion & $\mathrm{V}$ & $\mathrm{V}$ & $\mathrm{V}$ & $\mathrm{V}$ & V & $\mathrm{V}$ & $\mathrm{V}$ & V \\
\hline Sesleria caerulea & Seslerion & I & $\mathrm{V}$ & IV & $\mathrm{V}$ & $\mathrm{V}$ & II & $\mathrm{V}$ & $\mathrm{V}$ \\
\hline Festuca quadriflora & Caricion firmae & $\mathrm{V}$ & $\mathrm{V}$ & $\mathrm{V}$ & IV & III & III & II & III \\
\hline Minuartia verna & Seslerion & $\mathrm{V}$ & IV & IV & IV & III & II & IV & II \\
\hline Aster alpinus & Seslerion & I & IV & IV & IV & IV & III & $\mathrm{V}$ & II \\
\hline Agrostis alpina & Elynion & II & $\mathrm{V}$ & IV & IV & III & II & IV & II \\
\hline Elyna myosuroides & Elynion & IV & $\mathrm{V}$ & II & III & I & $\mathrm{I}$ & I & $\mathrm{r}$ \\
\hline Galium pumilum & Calluno-Genistion & $\mathrm{r}$ & $\mathrm{r}$ & IV & II & III & $\mathrm{r}$ & III & $\mathrm{r}$ \\
\hline Gentiana verna & Seslerion & I & III & IV & II & II & II & III & $\mathrm{r}$ \\
\hline Thymus serpyllum aggr. & & $\mathrm{r}$ & II & III & III & IV & IV & $\mathrm{V}$ & $\mathrm{r}$ \\
\hline Campanula cochleariifolia & Cystopteridion & II & $\mathrm{r}$ & I & III & II & $\mathrm{r}$ & $\mathrm{r}$ & I \\
\hline \multicolumn{10}{|l|}{ Differential species group 3} \\
\hline Saxifraga oppositifolia & Thlaspion rotundifolii & $\mathrm{V}$ & III & II & II & I & & $\mathrm{r}$ & \\
\hline Carex rupestris & Caricion firmae & $\mathrm{V}$ & I & $\mathrm{r}$ & IV & $\mathrm{r}$ & & & \\
\hline Herniaria alpina & Drabion hoppeanae & IV & $\mathrm{r}$ & IV & II & & I & II & \\
\hline Gentiana schleicheri & Drabion hoppeanae & IV & I & III & II & & & & \\
\hline Linaria alpina s.str. & Thlaspion rotundifolii & III & $\mathrm{r}$ & I & $\mathrm{r}$ & & & II & \\
\hline Draba dubia & Androsacion vandellii & III & $\mathrm{r}$ & $\mathrm{r}$ & I & & & & \\
\hline \multicolumn{10}{|l|}{ Differential species group 2} \\
\hline Polygonum viviparum & Caricion curvulae & III & $\mathrm{V}$ & $\mathrm{r}$ & III & III & $\mathrm{r}$ & & II \\
\hline Campanula scheuchzeri & & & IV & III & II & III & I & I & $\mathrm{r}$ \\
\hline Arenaria ciliata & Elynion & III & III & II & $\mathrm{I}$ & $\mathrm{r}$ & & & $\mathrm{r}$ \\
\hline Ligusticum mutellinoides & Elynion & III & III & II & & $\mathrm{r}$ & $\mathrm{r}$ & & \\
\hline Pedicularis verticillata & Seslerion & & III & $\mathrm{r}$ & I & I & & & $\mathrm{r}$ \\
\hline Silene acaulis & Caricion firmae & & III & $\mathrm{r}$ & $\mathrm{r}$ & $\mathrm{r}$ & & & I \\
\hline \multicolumn{10}{|l|}{ Differential species group 6} \\
\hline Draba aizoides & Drabo-Seslerion & IV & II & $\mathrm{V}$ & II & I & II & II & \\
\hline Carex curvula s.l. & Elynion / Caricion curvulae & & II & IV & $\mathrm{r}$ & & I & & \\
\hline Sempervivum arachnoideum & Sedo-Scleranthion & $\mathrm{r}$ & II & IV & II & I & III & III & \\
\hline Artemisia glacialis & Androsacion vandellii & & & III & & $\mathrm{r}$ & III & & \\
\hline Veronica fruticans & Festucion variae & & $\mathrm{r}$ & III & $\mathrm{r}$ & $\mathrm{r}$ & I & II & \\
\hline Oxytropis helvetica & Seslerion & II & & III & $\mathrm{r}$ & & & & \\
\hline \multicolumn{10}{|l|}{ Differential species group 1} \\
\hline Senecio doronicum & Seslerion & & $\mathrm{r}$ & III & III & V & II & IV & \\
\hline Carex sempervirens & Seslerion & & III & $\mathrm{r}$ & III & $\mathrm{V}$ & I & I & $\mathrm{r}$ \\
\hline Anthyllis vulneraria subsp. alpestris & Seslerion & & II & I & II & IV & I & II & II \\
\hline Festuca violacea aggr. & Caricion ferrugineae & & r & II & I & III & r & I & \\
\hline Phyteuma orbiculare & Seslerion & & $\mathrm{r}$ & & & III & & & \\
\hline Scabiosa lucida & Seslerion & & $\mathrm{r}$ & & & III & & & \\
\hline \multicolumn{10}{|l|}{ Differential species group 7} \\
\hline Bupleurum ranunculoides s.str. & Seslerion & & $\mathrm{r}$ & $\mathrm{r}$ & II & I & III & $\mathrm{V}$ & \\
\hline Euphorbia cyparissias & Mesobromion & & $\mathrm{r}$ & II & $\mathrm{r}$ & II & II & $\mathrm{V}$ & \\
\hline Carex humilis & Stipo-Poion & & $\mathrm{r}$ & & I & II & $\mathrm{r}$ & $\mathrm{V}$ & \\
\hline Oxytropis campestris s.str. & Elynion & & II & II & I & II & III & IV & \\
\hline Dianthus sylvestris & Drabo-Seslerion & & & $\mathrm{r}$ & $\mathrm{r}$ & $\mathrm{r}$ & III & IV & \\
\hline Acinos alpinus & Drabo-Seslerion & & $\mathrm{r}$ & I & $\mathrm{r}$ & II & II & IV & \\
\hline Hieracium pilosella & Mesobromion & & & I & I & $\mathrm{r}$ & II & IV & \\
\hline Koeleria macrantha & Stipo-Poion & & & $\mathrm{r}$ & & & II & IV & \\
\hline
\end{tabular}


Carlina acaulis subsp. caulescens

Teucrium montanum

Astragalus australis

Plantago serpentina

Pulsatilla halleri

Erysimum rhaeticum

Campanula rotundifolia

Trifolium montanum

Astragalus leontinus

Briza media

Carex caryophyllea

Galium lucidum

Dactylis glomerata

Linum catharticum

\section{Differential species group 8}

Dryas octopetala

Saxifraga caesia

Carex mucronata

Gentiana clusii

Carex firma

Crepis kerneri

\section{Other species}

Helianthemum alpestre

Carduus defloratus s.l.

Galium anisophyllon

Euphrasia salisburgensis

Sedum atratum

Gypsophila repens

Euphrasia minima

Helianthemum nummularium s.l.

Festuca ovina aggr.

Lotus corniculatus aggr.

Cerastium arvense subsp. strictum

Gentiana campestris s.str.

Hieracium villosum

Globularia cordifolia

Juniperus communis subsp. nana

Silene exscapa

Euphrasia alpina

Anthyllis vulneraria subsp. valesiaca

Leucanthemum adustum

Botrychium lunaria

Carex ericetorum

Erigeron alpinus

Gentiana nivalis

Hippocrepis comosa

Myosotis alpestris

Poa alpina

Salix serpillifolia

Saxifraga paniculata

Biscutella laevigata

Calamagrostis varia

Erigeron uniflorus

Leontodon hispidus s.l.

Potentilla crantzii

Saxifraga exarata s.l.

Trisetum distichophyllum

Arctostaphylos uva-ursi

Oxytropis halleri s.l.

Sempervivum montanum

Antennaria carpatica
Mesobromion

Stipion calamagrostis

Seslerion

Sedo-Scleranthion

Stipo-Poion

Stipo-Poion

Asplenion serpentini

Cirsio-Brachypodion

Seslerion

Mesobromion

Mesobromion

Xerobromion

Arrhenatherion

Caricion firmae

Caricion firmae

Caricion firmae

Caricion firmae

Caricion firmae

Caricion firmae

Drabo-Seslerion

Seslerion

Seslerion

Drabo-Seslerion

Drabo-Seslerion

Epilobion fleischeri

Caricion curvulae

Sedo-Scleranthion

Calluno-Genistion

Seslerion

Drabo-Seslerion

Juniperion nanae

Caricion curvulae

Festucion variae

Festucion variae

Erico-Pinion sylvestris

Nardion

Elynion

Seslerion

Elynion

Xerobromion

Caricion ferruginae

Poion alpinae

Drabion hoppeanae

Potentillion

Androsacion vandellii

Caricion ferruginae

Elynion

Poion alpinae

Seslerion

Androsacion vandellii

Petasition paradoxi

Juniperion sabinae

Elynion

Sedo-Scleranthion

Elynion

$\begin{array}{cccccc}\text { r } & \text { r } & \text { I } & \text { II } & \text { I } & \text { IV } \\ & \text { r } & \text { I } & \text { r } & \text { I } & \text { IV } \\ & \text { r } & \text { I } & \text { I } & \text { II } & \text { III } \\ & \text { r } & \text { r } & \text { r } & \text { II } & \text { III } \\ & \text { I } & \text { r } & \text { r } & \text { II } & \text { III } \\ & \text { r } & & \text { I } & \text { II } & \text { III } \\ \text { r } & & \text { I } & \text { I } & \text { I } & \text { III } \\ \text { r } & & \text { r } & \text { r } & \text { r } & \text { III } \\ & \text { r } & & \text { r } & \text { I } & \text { III } \\ & & \text { r } & \text { I } & \text { r } & \text { III } \\ \text { r } & & & \text { r } & \text { r } & \text { III } \\ & & \text { r } & \text { r } & \text { I } & \text { III } \\ & & & & \text { r } & \text { III } \\ & & & \text { I } & & \text { III }\end{array}$

$\begin{array}{ccccccc}\text { II } & \text { r } & \text { I } & \text { II } & & & \text { V } \\ \text { r } & & \text { I } & \text { r } & & & \text { V } \\ & \text { r } & \text { r } & \text { r } & \text { I } & \text { r } & \text { IV } \\ \text { I } & & \text { I } & \text { II } & & & \text { IV } \\ & & \text { I } & \text { r } & & & \text { IV } \\ & & \text { r } & & & & \text { III }\end{array}$

$\begin{array}{cccccccc} & \text { II } & \text { II } & \text { IV } & \text { III } & \text { II } & \text { III } & \text { V } \\ & \text { r } & \text { I } & \text { I } & \text { IV } & \text { r } & \text { IV } & \text { r } \\ \text { r } & \text { III } & \text { IV } & \text { III } & \text { II } & \text { I } & \text { IV } & \\ & \text { I } & \text { r } & \text { II } & \text { III } & \text { r } & \text { II } & \text { I } \\ \text { III } & \text { I } & \text { I } & \text { I } & \text { II } & \text { I } & & \text { r } \\ \text { I } & & \text { r } & \text { III } & \text { II } & \text { I } & \text { III } & \text { r }\end{array}$

$\begin{array}{ccccccc}\text { I } & \text { III } & \text { II } & \text { I } & \text { I } & \text { I } & \text { I } \\ & \text { I } & \text { II } & \text { II } & \text { V } & \text { II } & \text { V }\end{array}$

IV

IV

II

I

II I

III II

III

III II II $\mathrm{r}$ II

III

III

III

I

$r$

II

$r$

I $r$

r r

$\begin{array}{lllllll}r & \text { II } & \text { II } & \text { r } & \text { II } & \text { I } & \end{array}$

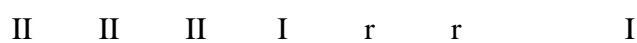

$\begin{array}{lllllll}\text { II } & \text { II } & \text { II } & \text { II } & \text { II } & \text { I } & \text { r }\end{array}$

$\begin{array}{llllll}r & r & I I & r & r & \text { II } \\ -r & r & \text { II } & r & r & r\end{array}$

$\begin{array}{llllll}\text { II } & \text { II } & \mathrm{r} & \mathrm{I} & \mathrm{I} & \mathrm{r}\end{array}$

II

I

$\begin{array}{llcllll}r & \text { r } & \text { II } & \text { I } & \text { r } & \text { I } & \\ r & & \text { I } & \text { r } & \text { r } & \text { I } & \text { II }\end{array}$

$\begin{array}{lllllll}r & r & I & I & I & r\end{array}$

$\begin{array}{llllllll} & \text { I } & \text { I } & \text { I } & \text { r } & \text { r } & \text { r } & \\ \text { I } & \text { II } & \text { r } & & \text { r } & & & \text { r }\end{array}$ 
Antennaria dioica

Anthoxanthum odoratum aggr.

Chamorchis alpina

Juniperus sabina

Lloydia serotina

Oxytropis lapponica

Pedicularis tuberosa

Potentilla grandiflora

Primula farinosa

Pulsatilla vernalis

Ranunculus montanus aggr.

Cirsium acaule

Primula hirsuta

Salix retusa

Arabis ciliata

Artemisia umbelliformis

Bartsia alpina

Carex capillaris

Festuca halleri aggr.

Gentiana brachyphylla

Gentiana tenella

Helictotrichon versicolor

Minuartia sedoides

Nigritella rhellicani

Poa perconcinna

Polygala alpestris

Sempervivum tectorum subsp. alpinum

Silene nutans s.str.

Thesium alpinum

Viola rupestris

Agrostis rupestris

Allium lusitanicum

Aster bellidiastrum

Carex ornithopoda

Draba siliquosa

Festuca varia aggr.

Kernera saxatilis

Luzula spicata s.l.

Parnassia palustris

Pedicularis kerneri

Primula auricula

Hieracium piliferum aggr.

Juncus trifidus

Viola pinnata

Androsace chamaejasme

Athamanta cretensis

Daphne striata

Erica carnea

Gentiana utriculosa

Juncus jacquinii

Phleum phleoides

Poa violacea

Soldanella alpina

Taraxacum laevigatum aggr.

Thalictrum foetidum

Trifolium pratense s.l.

Achillea millefolium aggr.

Draba fladnizensis

Festuca arundinacea s.str.

Hieracium angustifolium

Homogyne alpina
Nardion

Nardion

Caricion firmae

Juniperion sabinae

Elynion

Elynion

Festucion variae

Festucion variae

Caricion davallianae

Caricion curvulae

Poion alpinae

Mesobromion

Androsacion vandellii

Arabidion caerulae

Seslerion

Androsacion vandellii

Caricion bicolori-atrofuscae

Caricion bicolori-atrofuscae

Caricion curvulae

Elynion

Elynion

Caricion curvulae

Caricion curvulae

Nardion

Stipo-Poion

Seslerion

Drabo-Seslerion

Festucion variae

Seslerion

Ononido-Pinion

Caricion curvulae

Alysso-Sedion

Seslerion

Seslerion

Elynion

Festucion variae

Potentillion

Caricion curvulae

Caricion davallianae

Caricion curvulae

Potentillion

Caricion curvulae

Caricion curvulae

Erico-Pinion mugo

Seslerion

Petasition paradoxi

Erico-Pinion mugo

Ericion

Caricion davallianae

Caricion curvulae

Festucion variae

Arabidion caerulae

Geranion sanguinei

Arrhenatherion

Arrhenatherion

Drabion hoppeanae

Agropyro-Rumicion

Caricion curvulae

Vaccinio-Piceion

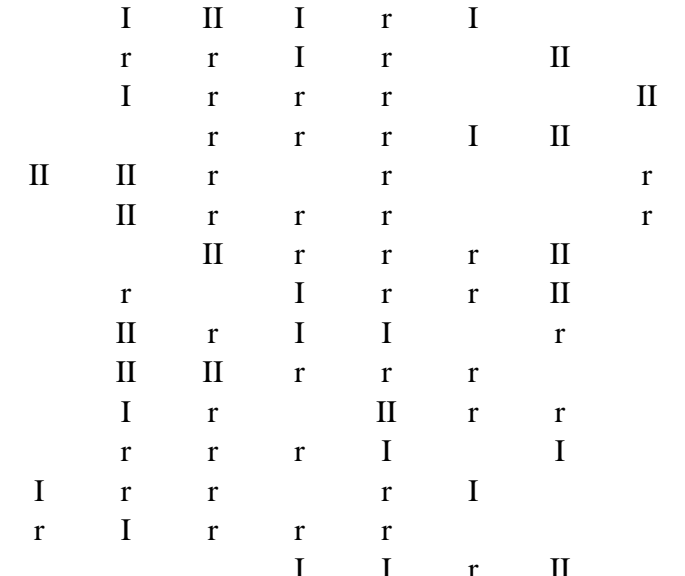

II $\quad$ r $\quad$ I $r$ r

$\begin{array}{llll}\text { II } & r & r & \text { II }\end{array}$

II

r

I

II

r $\quad r$

I

r

I

II

r I

I II

I

I

I I

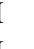

r

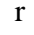

$\begin{array}{lllllll} & \text { r } & \text { I } & & \text { I } & \text { I } & \\ & & \text { I } & \text { r } & & \text { I } & \text { r } \\ \text { I } & \text { I } & \text { I } & & \text { r } & & \end{array}$

I

I

II

II

II

II

II $r \quad r$

II $\mathrm{r} \quad \mathrm{I}$

I II

I

I

r

II

r II

I

r

$\begin{array}{llll} & \text { I } & \text { I } & \text { I } \\ \text { I } & \mathrm{r} & & \text { I }\end{array}$ 
Minuartia mutabilis

Minuartia recurva

Caricion curvulae

Myosotis stricta

Phyteuma hemisphaericum

Rhamnus pumila

Saxifraga bryoides

Selaginella selaginoides

Senecio incanus s.str.

Silene rupestris

Silene vulgaris s.str.

Stipa eriocaulis s.str.

Thalictrum minus s.l.

Artemisia genipi

Carex liparocarpos

Carex ornithopodioides

Centaurea scabiosa s.l.

Cirsium spinosissimum

Gentiana engadinensis

Luzula lutea

Oxytropis fetida

Phyteuma globulariifolium s.l.

Poa bulbosa

Polygala alpina

Potentilla aurea

Silene vulgaris subsp. glareosa

Solidago virgaurea subsp. minuta

Taraxacum dissectum

Veronica fruticulosa

Astragalus sempervirens

Hedysarum hedysaroides

Hieracium bifidum aggr.

Scabiosa columbaria s.str.

Anthyllis vulneraria s.str.

Coeloglossum viride

Erigeron neglectus

Festuca rubra aggr.

Helictotrichon pubescens

Hieracium tomentosum

Koeleria vallesiana

Plantago alpina

Poa laxa

Polygala chamaebuxus

Potentilla frigida

Pulsatilla alpina s.str.

Rhinanthus minor

Saussurea alpina s.str.

Stachys recta s.str.

Stipa pennata

Androsace obtusifolia

Androsace vitaliana

Astragalus frigidus

Carex nigra

Cotoneaster integerrimus

Dianthus glacialis

Echium vulgare

Erigeron glabratus

Gentiana orbicularis

Gentiana ramosa

Geum montanum

Laserpitium siler

Leontodon helveticus

Sedo-Veronicion

Caricion curvulae

Potentillion

Androsacion alpinae

Caricion bicolori-atrofuscae

Caricion curvulae

Sedo-Scleranthion

Arrhenatherion

Stipo-Poion

Geranion sanguinei

Stipo-Poion

Arabidion caerulae

Mesobromion

Rumicion alpinii

Seslerion caeruleae

Caricion curvulae

Drabion hoppeanae

Caricion curvulae

Sedo-Veronicion

Caricion firmae

Nardion

Petasition paradoxi

Epilobion angustifolii

Caricion firmae

Drabo-Seslerion

Caricion ferruginae

Seslerion

Mesobromion

Mesobromion

Nardion

Elynion

Cynosurion

Arrhenatherion

Potentillion

Stipo-Poion

Nardion

Androsacion alpinae

Ericion

Caricion curvulae

Caricion ferruginae

Molinion

Elynion

Xerobromion

Cirsio-Brachypodion

Caricion curvulae

Androsacion alpinae

Caricion ferruginae

Caricion fuscae

Juniperion nanae

Elynion

Dauco-Melilotion

Seslerion

Drabion hoppeanae

Festucion variae

Nardion

Stipion calamagrostis

Nardion

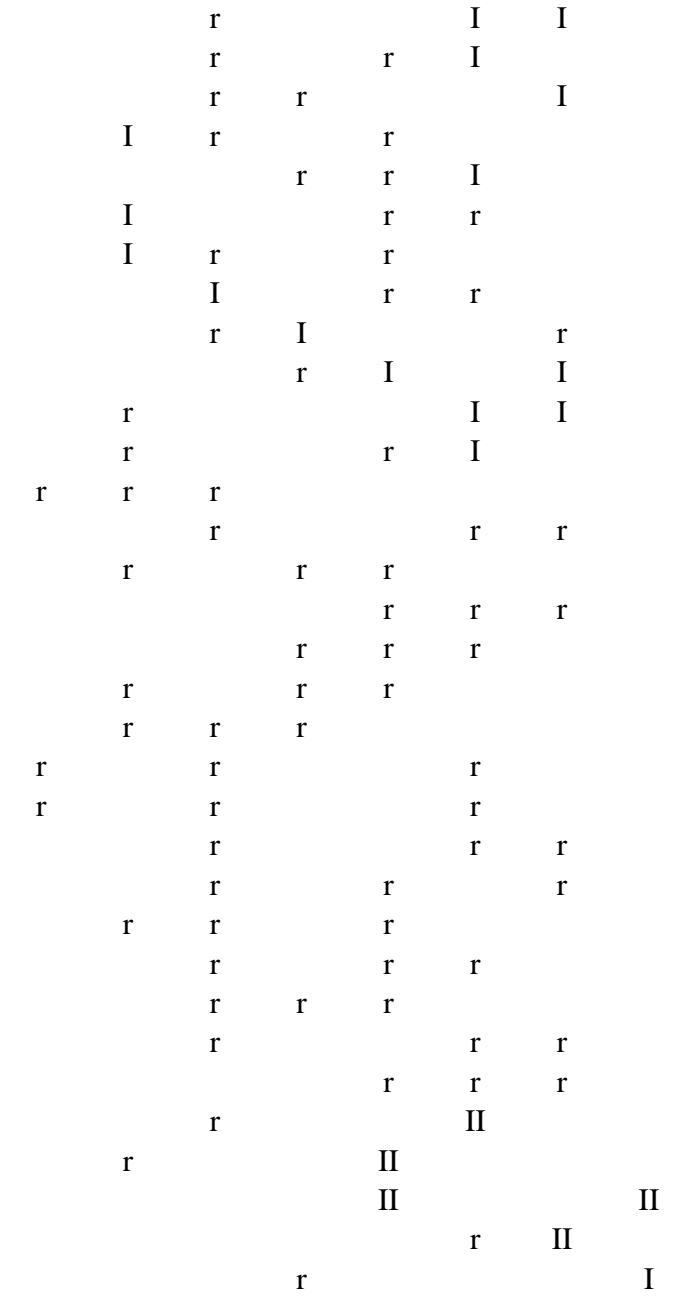

r

I

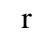

r

I

r

$\mathrm{r}$

I

r

r

I

I

r

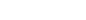

r

r r

r

r

r

(1)


Leontodon incanus s.str.

Linum alpinum

Oxytropis jacquinii

Pinus cembra

Plantago atrata s.str.

Poa nemoralis

Salix reticulata

Taraxacum alpinum aggr.

Tephroseris capitata

Veronica aphylla

Viola calcarata

Androsace puberula

Astragalus monspessulanus

Cuscuta epithymum

Pinguicula alpina

Scutellaria alpina

Achillea erba-rotta subsp. moschata

Achillea nana

Asplenium ruta-muraria

Campanula thyrsoides

Carex atrata s.str.

Carex fimbriata

Carex flacca

Crepis alpestris

Daphne mezereum

Dianthus caryophyllus

Gymnadenia odoratissima

Helictotrichon parlatorei

Hieracium hoppeanum

Myosotis arvensis

Onobrychis montana

Phleum hirsutum

Poa molinerii

Potentilla caulescens

Rhinanthus glacialis

Sanguisorba minor s.str.

Valeriana montana

Alchemilla conjuncta aggr.

Anemone baldensis

Artemisia borealis

Luzula multiflora

Potentilla erecta

Stemmacantha rhapontica s.str.
Erico-Pinion sylvestris

Seslerion

Seslerion

Poion alpinae

Tilion platyphylli

Arabidion caerulae

Arabidion caerulae

Seslerion

Poion alpinae

Caricion curvulae

Ononido-Pinion

Caucalidion

Cratoneurion

Seslerion

Androsacion alpinae

Drabion hoppeanae

Potentillion

Caricion ferruginae

Elynion

Caricion curvulae

Molinion

Erico-Pinion mugo

Cephalanthero-Fagenion

Festucion variae

Molinio-Pinion

Festucion variae

Caucalidion

Seslerion

Caricion ferruginae

Alysso-Sedion

Potentillion

Nardion

Mesobromion

Petasition paradoxi

Seslerion

Thlaspion rotundifolii

Drabion hoppeanae

Nardion

Calamagrostion

$\begin{array}{lll}r & \\ r & \\ r & & \\ r & & \\ r & & \\ r & r & r \\ r & & \\ & & \end{array}$

II

II

II

II

I

I

I

I

I

I

I

I

I

I

I

I

I

I

I

I

I

I

I

I

r

r

r

Mean number of species 